\title{
Genetic Manipulation for Improved Nutritional Quality in Rice
}

\author{
Priyanka Das ${ }^{\star}$, Sanghamitra Adak ${ }^{\dagger}$ and Arun Lahiri Majumder* \\ Division of Plant Biology, Bose Institute, Kolkata, India
}

\section{OPEN ACCESS}

Edited by:

Qiaoquan Liu,

Yangzhou University, China

Reviewed by:

Untung Susanto,

Indonesian Agency for Agricultural Research and Development (IAARD), Indonesia

Partha S. Biswas,

Bangladesh Rice Research Institute Bangladesh

*Correspondence:

Priyanka Das

prink.bot@gmail.com Arun Lahiri Majumder

lahiri@jcbose.ac.in;

alahirimajumder@yahoo.com;

lahiri@mail.jcbose.ac.in

tThese authors have contributed equally to this work

Specialty section: This article was submitted to Nutrigenomics,

a section of the journal

Frontiers in Genetics

Received: 31 January 2020 Accepted: 30 June 2020

Published: 24 July 2020

Citation:

Das P, Adak S and

Lahiri Majumder A (2020) Genetic

Manipulation for Improved Nutritional Quality in Rice. Front. Genet. 11:776.

doi: 10.3389/fgene.2020.00776
Food with higher nutritional value is always desired for human health. Rice is the prime staple food in more than thirty developing countries, providing at least $20 \%$ of dietary protein, $3 \%$ of dietary fat and other essential nutrients. Several factors influence the nutrient content of rice which includes agricultural practices, post-harvest processing, cultivar type as well as manipulations followed by selection through breeding and genetic means. In addition to mutation breeding, genetic engineering approach also contributed significantly for the generation of nutrition added varieties of rice in the last decade or so. In the present review, we summarize the research update on improving the nutritional characteristics of rice by using genetic engineering and mutation breeding approach. We also compare the conventional breeding techniques of rice with modern molecular breeding techniques toward the generation of nutritionally improved rice variety as compared to other cereals in areas of micronutrients and availability of essential nutrients such as folate and iron. In addition to biofortification, our focus will be on the efforts to generate low phytate in seeds, increase in essential fatty acids or addition of vitamins (as in golden rice) all leading to the achievements in rice nutrition science. The superiority of biotechnology over conventional breeding being already established, it is essential to ascertain that there are no serious negative agronomic consequences for consumers with any difference in grain size or color or texture, when a nutritionally improved variety of rice is generated through genetic engineering technology.

Keywords: nutrition, rice, biotechnology, breeding, micronutrient

\section{INTRODUCTION}

Nutrition is the foremost requirement for an organism to operate vital functions such as growth, development, and reproduction. Plants acquire nutrition through the process of photosynthesis using $\mathrm{H}_{2} \mathrm{O}$ and $\mathrm{CO}_{2}$, in the presence of light. Apart from $\mathrm{H}$ and $\mathrm{C}, 15$ other elements are important for the development of major plant species (White and Brown, 2010). Furthermore, macronutrients $(\mathrm{S}, \mathrm{P}, \mathrm{Mg}, \mathrm{Ca}, \mathrm{K}, \mathrm{N}, \mathrm{O}, \mathrm{C}, \mathrm{H}$ ) and micronutrients $(\mathrm{Mo}, \mathrm{Ni}, \mathrm{Cu}, \mathrm{Zn}, \mathrm{Mn}, \mathrm{B}, \mathrm{Fe}, \mathrm{Cl}$ ) are also essential parts of plants nutrition (White and Brown, 2010). Being incapable of photosynthesis, animals including human beings depend upon plants for supporting their nutrition requirement either directly or indirectly.

Plant nutrients fulfilling human needs are called phytonutrients and different plants may contain different nutrients of altered levels. Hence, a single plant is not enough to gratify human nutritional needs. In recent times, contemporary agriculture is focusing on human nutritional improvement by generating improved varieties of staple crops such as rice, wheat, maize and grain legumes (Ricachenevsky et al., 2019). Grain legumes fulfill the requirement of protein and cereal crops have 
a high level of carbohydrate which offers $\sim 80 \%$ of calorie intake (Lafiandra et al., 2014; Shewry and Hey, 2015). Yet, cereals or legumes lack sources of important micro- and macro-nutrients, which can result in serious human health problems. Hence, a major part of ongoing staple plant research is focusing on the enhancement of the nutritional value of crops with aiming to increase the micro- and macro-nutrients. Rice is the major staple food crop for about half of the world's population whose nutritional status is a topic of discussion in the research sector. This principal staple food crop contains a reduced quantity of many essential micro- and macro- elements such as vitamins, minerals, some phytochemicals, essential amino acids and fatty acids, which are indispensable to human health (Birla et al., 2017). Elevation of nutritional quality of rice has been a great effort over the last decades either by traditional breeding, marker assisted breeding or by genetic or transgenic methods.

Human nutrition is completely dependent on plant systems directly or indirectly. Efforts have been taken for long to improve the nutritional quality of staple crops as these are the main sources of food with a low amount of micronutrients. The application of genomics to nutrition science is called "nutritional genomics" or "nutrigenomics" where identification of plant genes with nutritional importance is a significant step (DellaPenna, 1999). Precisely the discipline nutrigenomics refers to the interplay between plant biochemistry, genomics and nutrition in humans (DellaPenna, 1999). In the present review, we intend to focus on the importance of rice crop in terms of its nutritional value, health benefits, and need for enhancement of rice nutrition through biotechnology and conventional and/or molecular breeding approach.

\section{NUTRITIONAL VALUE AND HEALTH BENEFITS OF RICE}

Rice is the chief source of carbohydrate and is used as an integral part of a balanced diet for billions of people in the world. Rice is the extensively grown food crop occupying about millions hectares of farmlands (Muthayya et al., 2014). Rice grain has a high biological value for its high energy and high calories. Beyond the classification of long grain and short-grain rice types, other known types of rice are brown rice, white rice, polished rice, organic rice, wild rice, puffed rice, colored rice, etc. Brown and white rice are preferentially used as food by the major parts of the world population.

A comparison of nutrients of different staple foods is provided in Table 1. Apart from carbohydrates, rice contains a very low amount of phosphorous, iron and protein. It also has some quantity of calcium. In comparison to other food crops like maize, wheat, tuber roots and legumes, rice grain is also very low in mineral content (Mahender et al., 2016) and a small amount of vitamin B. Most of the nutrients and minerals are concentrated in the outer brown layer of the grain. Rice bran from the brown layer is an important source of nutrients such as vitamins, proteins, minerals and antioxidants (tocotrienols and gamma oryzanol) (Tian et al., 2004; Iqbal et al., 2005; Schramm et al., 2007). Hence, brown rice is the most nutritious among all types of rice. Comparative value of the nutrient composition between brown rice and white rice has been given in Table 2 .

Rice supplies complex carbohydrates that are broken down into glucose and the major part of glucose is used as energy and as vital fuel for the brain. Brown rice has a slow starch digestibility and some starch is never turned into sugar at all and reaches the large intestine intact (Dolson, 2009). Hence, Type II diabetic rice eaters would be better off eating brown rice instead of white rice. Eating brown or whole grain rice is known to lower down the risk of diabetes (Sun et al., 2010).

Rice is an exceptional food for a balanced diet as it has no cholesterol, fat or, sodium. Its' bran contains up to $80 \%$ fatty acids. Rice oils comprise the unsaturated fatty acid such as linoleic acid and oleic acid which cannot be synthesized by humans but are essential in maintaining the cell membranes and the nervous system functions (Frei and Becker, 2004). Rice is a significant source of protein having eight of the necessary amino acids in a balanced amount which play a great role in healthy hair and skin, better eyesight, heart and lungs nourishment, better nervous system and brain function. Recently, a comparison of rice bran protein was carried out with vegetable and animal protein. The digestibility index explains that rice bran protein was significantly higher $(94.8 \%)$ than rice endosperm protein. Other sources like soy protein $(91.7 \%)$ and whey protein $(92.8 \%)$ exhibited comparatively lower digestibility than rice bran protein (Han et al., 2015).

The B-complex vitamins (riboflavin, niacin and thiamine) of brown rice support nourishment to blood vessels and skin. Rice bran also contains beneficial anti-oxidants of the Vitamin E family (Lloyd et al., 2000). Rice tocopherols and tocotrienols are found to have anti-cancer activities (Lloyd et al., 2000; Kline et al., 2004). Rice oryzanols have the capacity to lessen the absorption of cholesterol (Lloyd et al., 2000). It has also been investigated that tocotrienol of rice bran can stop blood clots which may lead to strokes (Frei and Becker, 2004). Furthermore, red rice bran is loaded in tannins and anthocyanins which have antiinflammatory properties. In addition, tannins have anti-bacterial effects and known to prevent cardiovascular diseases and cancer (Chung et al., 1998; Redondo et al., 2014). Black and red rice are rich in iron and zinc (Ahuja et al., 2008) which are needed for hemoglobin production and enzymatic processes respectively. Rice also provides important minerals like potassium, manganese and copper which are needed in the human body for normal metabolism, brain and nerve functions. Minerals in natural brown rice have a role in nourishing the hormonal system, regulating blood pressure and heal wounds. Rice also provides iron, phosphorus and potassium along with other nutrients to improve the bloodstream and to uphold inner water balance and internal harmony.

\section{NEED OF IMPROVEMENT OF THE NUTRITIONAL QUALITY OF RICE}

Micronutrients are required for a healthy human being and their recommended daily allowances are presented in Table 3. Micronutrient deficiency is a major problem for the rice eaters. 
TABLE 1 | Comparison of nutrients in different staple foods (per $100 \mathrm{~g}$ ) (FAO http://www.fao.org/3/t0567e/T0567E0d.htm).

\begin{tabular}{lcccc}
\hline Nutrients & Brown rice & Wheat & Maize & Potato \\
\hline Protein (g) & 7.3 & 10.6 & 9.8 & 2 \\
Fat $(\mathrm{g})$ & 2.2 & 1.9 & 4.9 & 0.1 \\
Carbohydrate $(\mathrm{g})$ & 71.1 & 61.6 & 60.9 & 15.4 \\
Carotene $(\mathrm{mg})$ & 0 & 0.02 & 0.37 & 0 \\
Thiamine $(\mathrm{mg})$ & 0.29 & 0.45 & 0.32 & 0.11 \\
Riboflavin $(\mathrm{mg})$ & 0.04 & 0.1 & 0.1 & 0.05 \\
Vitamin E (mg) & 0.8 & 1.4 & 1.9 & 0.06 \\
Iron (mg\%) & 3 & 4 & 3 & 0.08 \\
Zinc $(\mathrm{mg})$ & 2 & 3 & 3 & 0.3 \\
Lysine $(\mathrm{g} / 16 \mathrm{~g} \mathrm{~N})$ & 3.8 & 2.3 & 2.5 & 6.3 \\
Threonine $(\mathrm{g} / 16 \mathrm{~g} \mathrm{~N})$ & 3.6 & 2.8 & 3.2 & 4.1 \\
Methionine $+\mathrm{cystine} \mathrm{(g/16} \mathrm{g} \mathrm{N)}$ & 3.9 & 3.6 & 3.9 & 3.6 \\
Tryptophan (g/16 g N) & 1.1 & 1 & 0.6 & 1.7 \\
\hline
\end{tabular}

TABLE 2 | Composition of nutrients in rice (per a cup of white or brown rice).

\begin{tabular}{lcc}
\hline Product & Brown rice & White rice \\
\hline Protein (g) & 5.54 & 4.43 \\
Fat (g) & 1.96 & 0.39 \\
Carbohydrate $(\mathrm{g})$ & 51.7 & 53.2 \\
Fiber (g) & 3.23 & 0.56 \\
Calories (Kcal) & 248 & 242 \\
Iron (mg) & 1.1 & 2.8 \\
Phosphorus (mg) & 208 & 68.8 \\
Magnesium (mg) & 78.8 & 24.2 \\
Zinc (mg) & 1.4 & 0.8 \\
Copper (mg) & 0.2 & 0.1 \\
Manganese (mg) & 2.0 & 0.7 \\
Thiamine & 0.4 & 0.3 \\
Vitamin B-6 (mg) & 0.3 & 0.1 \\
Niacin & 5.2 & 3.4 \\
Folate (mcg) & 18.2 & 108 \\
\hline
\end{tabular}

Newsletter, Medically reviewed by Natalie Butler, R.D., L.D. (2019) - Written by Megan Ware, RDN, LD.

Frequently, rice eaters increase the intake of rice without increasing other nutritionally enriched foods when there is a calorie demand. Many people do not opt for a nutritious diet that includes whole grains, protein, vegetables and fruits.

Outer wall to inner endosperm of rice contains different level of nutrients (Juliano, 1993). Although rice is a good source of vitamin B group, riboflavin, thiamine and niacin and asparticand glutamic acids, rice contains a low level of lysine (Grist, 1986; Juliano, 1993). Recent climate change has turned out a decrease in the nutrient content of rice as well as other cereal crops (Smith and Myers, 2019). A Rising level of $\mathrm{CO}_{2}$ in the atmosphere decreased the levels of protein, micronutrients and $B$ vitamins in rice which may impact a negative effect on fetal and child health in the rice dependant countries. The rice grown in increased $\mathrm{CO}_{2}$ concentrations contained $17 \%$ decreased vitamin B1, 17\% decreased vitamin B2, 13\% decreased vitamin B5 and $30 \%$ decreased vitamin $\mathrm{B} 9$ than the rice grown under regular $\mathrm{CO}_{2}$ concentrations. Average decline of $5 \%$ in zinc, $8 \%$ in iron
TABLE 3 | Micronutrients required for healthy human population (adapted from FAO/WHO, 2001, Human Vitamin and Mineral Requirements).

\begin{tabular}{|c|c|c|c|}
\hline \multicolumn{4}{|c|}{ Recommended nutrient intake for human health } \\
\hline Micronutrient types & Infants (0-6 months) & Adults & Pregnancy \\
\hline Thiamin (mg/day) & 0.2 & 1.2 & 1.4 \\
\hline Riboflavin (mg/day) & 0.3 & 1.3 & 1.4 \\
\hline Niacin $\left(\mathrm{NEs} /\right.$ day $\left.^{a}\right)$ & 2 & 16 & 18 \\
\hline Vit B6 (mg/day) & 0.1 & 1.3 & 1.9 \\
\hline Folate $\left(\mu \mathrm{g} /\right.$ day-RNI $\left.{ }^{\star}\right)$ & 80 & 400 & 600 \\
\hline Vit B12 ( $\mu \mathrm{g} /$ day-RNI*) & 0.4 & 2.4 & 2.6 \\
\hline Vit C (mg/day-RNI*) & 25 & 45 & 55 \\
\hline Vit A ( $\mu \mathrm{g}$ RE/day $\left.{ }^{+}\right)$ & 375 & 500 & 800 \\
\hline Vit $D(\mu \mathrm{g} /$ day-RNI*) & 5 & 10 & 5 \\
\hline Calcium (mg/day) & 300 & 1000 & 1200 \\
\hline lodine ( $\mu \mathrm{g} / \mathrm{kg} /$ day) & 15 & 2 & 3.5 \\
\hline Iron (mg/day) & 0.55 & 0.6 & 100 \\
\hline Zinc (mg/day) & 0.84 & 3.37 & 5 \\
\hline
\end{tabular}

NEs/day ${ }^{a}$ niacin equivalents. $R N I^{*}$ Reccomended nutrient intake. $R^{+}$Estimated mean requirement.

and $10 \%$ in protein have been reported (Smith and Myers, 2019). A number of factors influence the nutrient composition of rice as outlined in Figure 1. Research at International Rice Research Institute (IRRI) shows that nutrient content and composition can differ considerably between different varieties (Juliano and Villareal, 1993; Graham et al., 1999). Experiments under controlled environment showed that solar rays, soil nitrogen, extent of plant maturation and fertilizer application can alter protein, iron and zinc content (Graham et al., 1999; Iwata, 2002). Nitrogen level and soil type have effect on iron and zinc content in rice grains (Senadhira et al., 1998).

After harvesting the rice, storage, processing, washing and cooking practices can all influence its nutritional value, however, post-harvest losses are hardly ever taken into consideration for nutritional evaluation. The indirect effect of post-harvest nutrient losses in rice can have a deep impact on food safety. Postharvest loss is a quantifiable qualitative and quantitative loss in a specified product (Grewal and Sangha, 1990; Malik and Chaudhary, 2002). After harvesting, paddy rice is dehydrated and is then milled to eliminate the uneatable hull. Hulled rice or brown rice is composed of $2-3 \%$ embryo, $90 \%$ endosperm and $6-7 \%$ bran (Chen et al., 1998). Further elimination of the bran gives white rice. Paddy rice produces $65 \%$ white rice, $10 \%$ bran and 25\% hulls (Saunders and Betschart, 1979). In short, with further elimination of the bran layer more minerals and vitamins are lost (Malik and Chaudhary, 2002). Cleansing of rice, before cooking, leads to lose $2-7 \%$ protein, $11-26 \%$ riboflavin, $22-59 \%$ thiamine, $20-60 \%$ niacin and $20-41 \%$ potassium (Juliano, 1993). The cooking process of rice in India leads to a loss of $50 \%$ calcium and phosphorus, $10 \%$ protein and $75 \%$ iron. Cooking with excess water tends to lose more than $25 \%$ of riboflavin, thiamine and niacin (Saunders and Betschart, 1979). Frying rice with high temperatures can annihilate more than $50 \%$ of thiamine (Saunders and Betschart, 1979). Increasing the content of iron, zinc and provitamin A carotenoid in rice endosperm can lessen these nutrient deficiencies, particularly among the 


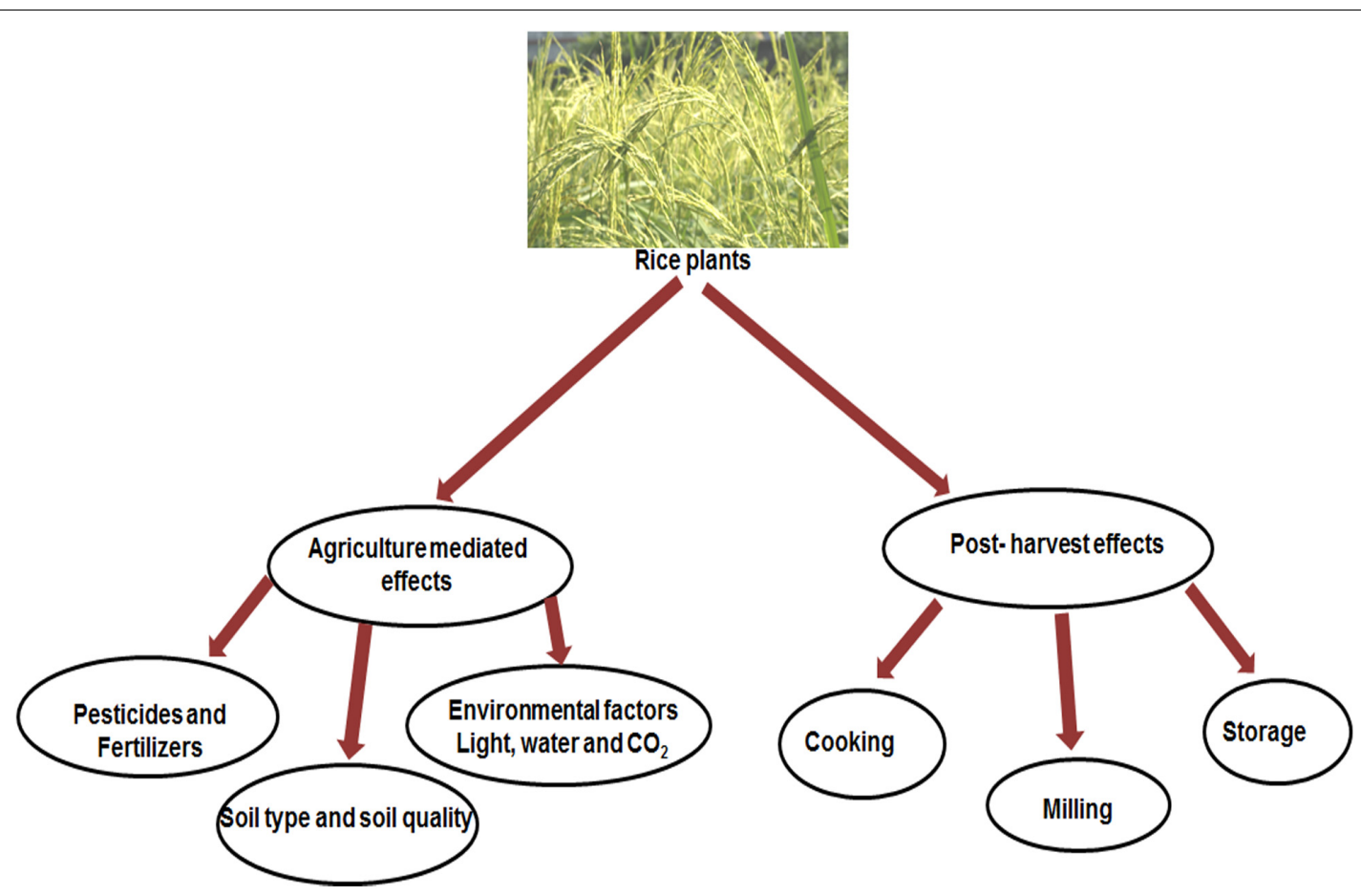

FIGURE 1 | Nutrient composition of rice as affected by various practices.

rural and urban poor people who do not have access to enriched foods and diversified diets. Hence, it is necessary to improve the nutritional quality of rice through the traditional breeding or emerging biotechnology method. Plant biologists adopted several approaches to meet this goal. A schematic strategy has been presented in Figure 2.

Yet, it is the topic of discussion that whether only an increase in micronutrient or amino acid or protein in the rice endosperm can considerably fulfill the nutrition requirement in rice dependant people. The nutritional status of the crop may also depend on proper growth of the plant and heavily influenced by the environmental conditions. Abiotic stresses such as salinity, drought and temperature extremes are other limiting factors for rice growth, development and yield. Hence, to adopt the micronutrient- or essential amino acid-rich rice varieties, the superior traits are preferred to be combined with other traits such as abiotic stress tolerance.

\section{MANIPULATION AT AMINO ACID AND PROTEIN LEVEL}

Humans have a great interest in increasing the levels of some essential amino acids in crop plants because of their incapability to produce the same. Crop genetic studies and genetic engineering technology wonderfully helped to succeed in enriching the important crop plants through enhancement of their essential amino acid and protein content. Specifically, lysine and tryptophan got much attention as their production is limiting in cereal crops. Genetic breeding methods have ended in comparatively limited success in some crop species due to a shortage of adequate quality genetic resources for plant breeding. Furthermore, genetic traits for high levels of lysine and tryptophan are generally linked with abnormal growth of the plant as these characters do not function in a seed-specific manner. On the other hand manipulation through genetic engineering approach worked great as it could allow seed-specific expression of specific characters of interest. An additional benefit of genetic engineering method is that the trait can be introduced into multiple plant species and genotypes. Yet, the advancement of metabolic pathways through genetic engineering too needs a thorough understanding of the interaction of regulatory network pathways that fine-tune plant growth and yield.

\section{MANIPULATION OF LYSINE CONTENT}

Lysine is an important amino acid for plants but its production in rice and other major crop plants is very low. Therefore, many of the rice researchers were devoted to understand the regulation of lysine metabolism and its utilization to increase the level of free lysine in the seeds. Some researchers are also interested in using the proteins which have high lysine content. Lysine is produced through a branch of the aspartate family pathway which also leads to the synthesis of two other essential amino acids, i.e., methionine and threonine (Galili, 2002; Figure 3). Fluctuation during the lysine biosynthesis part is regulated by a feedback inhibition ring where the activity of dihydrodipicolinate synthase (DHDPS) is inhibited by lysine, the earliest enzyme exclusively dedicated to the biosynthesis of 


\section{Rice varieties with}

low nutrition

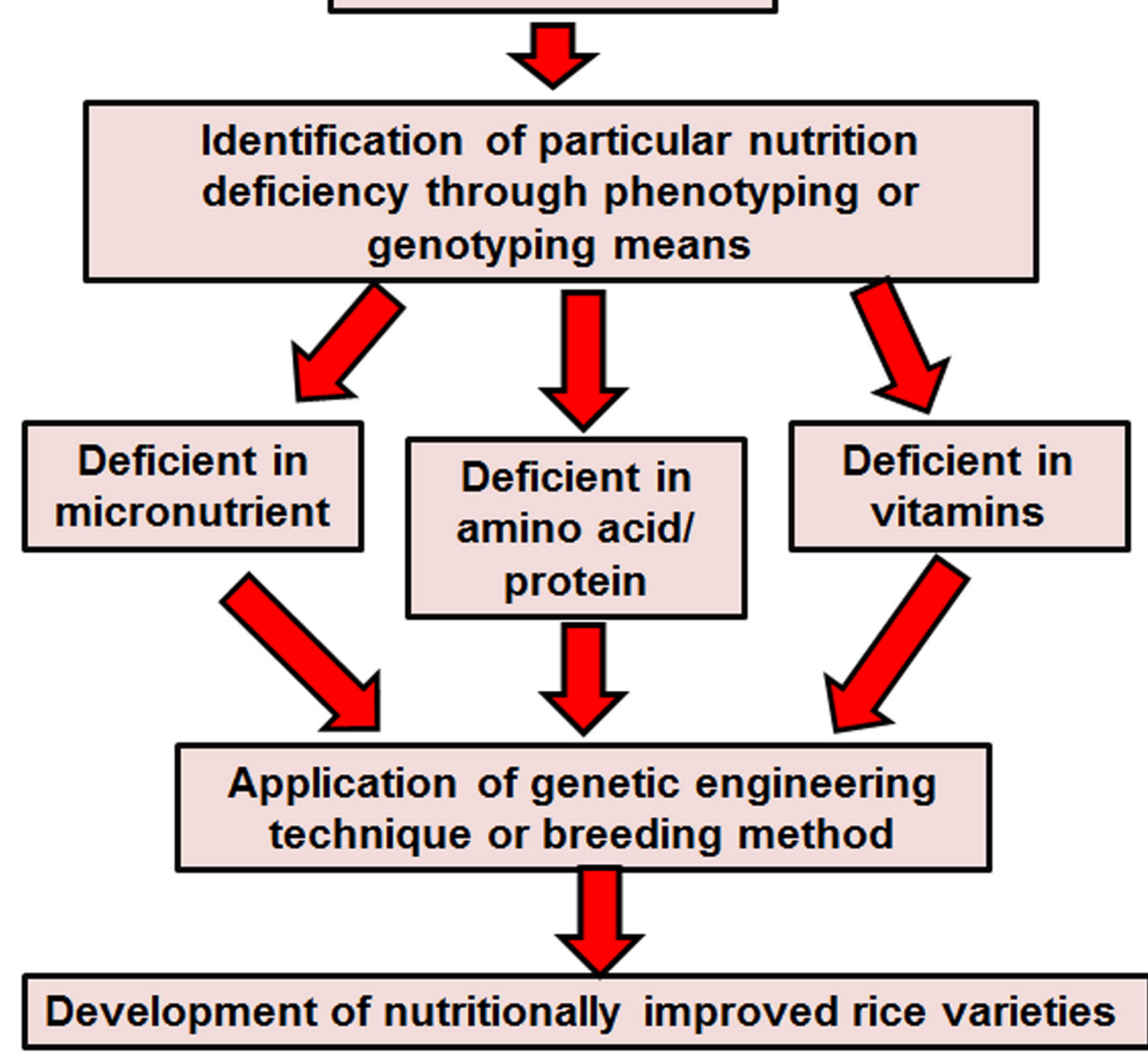

FIGURE 2 | Strategies for enhancement of nutrients in rice.

lysine (Galili, 2002). Genetic mutations in the tobacco DHDPS or constitutive expression of a bacterial lysine-insensitive DHDPS in transgenic tobacco or Arabidopsis plants caused overproduction of lysine in all plant parts (Negrutiu et al., 1984; Frankard et al., 1992; Shaul and Galili, 1992). High levels of lysine in all plant tissues can result in abnormal vegetative and reproductive growth, and reduced seed yield (Frankard et al., 1992; Shaul and Galili, 1992). For increasing cereal lysine content, an additional technique has been adapted in recent times which includes the introduction of lysine at alternative codons at the time of translation by using a recombinant tRNA-lysine ( $\mathrm{Wu}$ and Chen, 2003). Recombinant expression of this tRNA in transgenic rice could enhance seed lysine content significantly ( $\mathrm{Wu}$ and Chen, 2003). Stable expression of Arabidopsis Lys tRNA synthetase gene in maize plants caused significant enrichment of lysine content in the grain (Wu et al., 2007). Yang et al. (2016) targeted bacterial aspartate kinase and dihydrodipicolinate synthase into the intragenic region in the rice genome. Two pyramid transgenic lines (designated as High Free Lysine; HFL1 and HFL2) were obtained with $\sim 25$-fold higher lysine content in the seeds than the WT plants. The transgenic lines showed improved physicochemical properties with unchanged starch composition. Field performance showed a slight alteration in the height of the plant and seed color. Mature rice seeds with engineered HFL possessed the dark-brown appearance of endosperm. Yang et al. (2018) adopted transcriptomic and metabolomic approach and found increased serotonin biosynthesis which is linked with the color of endosperm in HFL rice. It was further confirmed by the overexpression of a key gene of serotonin biosynthesis, i.e., TDC3. It was evident from the study of Yang et al. (2018) that TDC expression and jasmonate signaling pathway were sturdily induced in the late phase of endosperm growth in HFL rice, corresponding with serotonin build up and darkbrown color development. This study is promoting the efforts to generate a nutritionally appreciative crop. In a different approach, Liu et al. (2016) took a lysine-rich protein (LRP) gene from Psophocarpus tetragonolobus using an endospermspecific promoter. The transgenic rice seeds revealed to have $30 \%$ more lysine than the WT plants. In addition, transgenic seeds have an increased level of other amino acids in comparison to the WT plant. The hybrid of the transgenic rice lines also revealed increased lysine content in the seeds. Two endogenous 


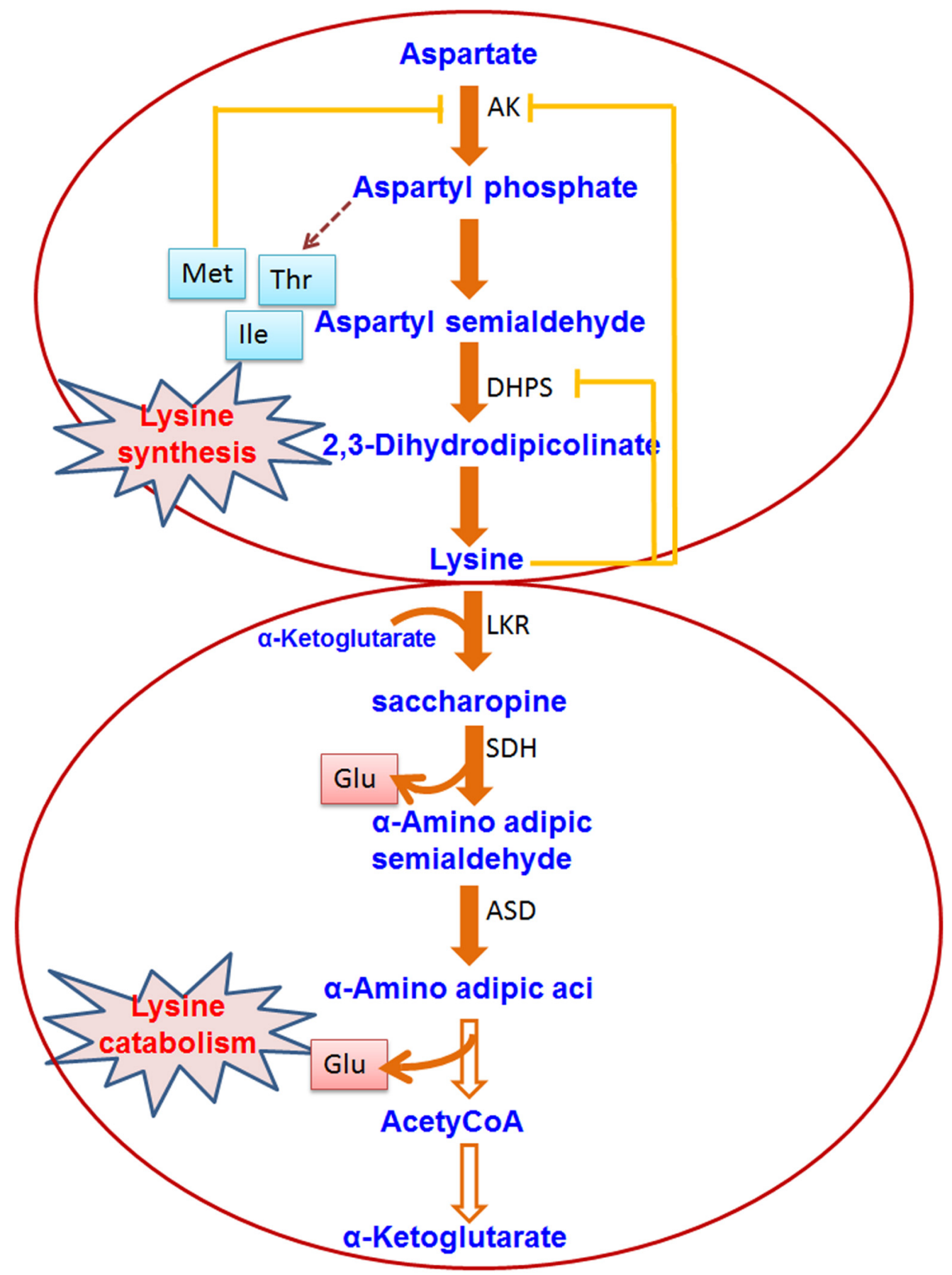

FIGURE 3 | Lysine biosynthesis and catabolism in plants. The pathway shows the biosynthesis/catabolism of Lysine. Enzymes involved in the pathway are indicated by abbreviations. The hollow/dashed arrow indicates non-specified enzymatic reactions (AK, Aspartate kinase; DHPS, dihydrodipicolinate synthase; LKR, lysine ketoglutaric acid reductase; SDH, saccharopine dehydropine dehydrogenase; ASD, aminoadipic-semialdehyde dehydrogenase).

lysine-rich histone proteins (RLRH1 and RLRH2) of rice were over-expressed in rice seeds to achieve lysine biofortification (Wong et al., 2015). The level of lysine in the seed of transgenic rice plants was increased up to $35 \%$, and other essential amino acids stayed balanced, as required by the dietary standards of the World Health Organization. Pseudo-cereal Amaranthus hypochondriacus has seed albumin (AmA1) rich in all the essential amino acids. The introduction of recombinant AmA1 in rice revealed increased $(1.06 \sim 12.87 \%)$ level total protein contents in the seeds of the transgenic plants than the wild type (Xu et al., 2017). Additionally, the level of other essential amino acids (e.g., lysine, valine, and threonine) was also increased significantly in 
the transgenic lines in comparison to the wild type counterpart (Xu et al., 2017). Binding protein is a molecular chaperon protein which works together with unfolded secretory proteins in the endoplasmic reticulum domain and supports their folding. Kawakatsu et al. (2010) showed that over-accumulation of lysinerich binding protein $(\mathrm{BiP})$ in transgenic rice plants resulted in high lysine germplasm and it offered a special strategy to increase the lysine content of the cereal grain.

\section{MANIPULATION OF THREONINE CONTENT}

In addition to low lysine, rice grains have also a very low level of threonine. Increase the threonine content has been shown to be intimately related to the lysine content in terms of regulation and several attempts have been made to achieve such feat. In a synthetic biology approach (Jiang et al., 2016) two genes were artificially synthesized by combining endogenous rice genes with lysine $(\mathrm{K}) /$ threonine $(\mathrm{T})$ motif (TKTKK) coding stretches. They were named as TKTKK1 and TKTKK2 with their respective proteins having 73.1 and $83.5 \%$ of lysine and threonine. Independent introduction of these two genes into the rice genome resulted in rice seeds with a significant increase in lysine $(33.87 \%)$, threonine $(21.21 \%)$, total amino acids $(19.43 \%)$ and crude protein $(20.45 \%)$ content as compared to wild type control plants (Jiang et al., 2016).

\section{MANIPULATION OF TRYPTOPHAN CONTENT}

Another limiting essential amino acid in cereals is tryptophan. The synthesis of tryptophan in plants is feedback regulated at the anthranilate synthase step responsible for its biosynthesis. Kreps et al. (1996) studied that insensitivity of anthranilate synthase to feedback inhibition by tryptophan enhances tryptophan accumulation. This study showed the way to use this trait to increase the level of tryptophan in cereals. Expression of analogous feedback-insensitive $a$-subunit of the rice anthranilate synthase caused a significant increase in the level of free tryptophan in the seeds but it also had negative effects on vital agronomical traits such as spikelet fertility, yield and germination (Wakasa et al., 2006). The feedback-insensitive $a$-subunit of the rice anthranilate synthase also revealed increased level the free tryptophan content in transgenic potato, Solanum tuberosum (Yamada et al., 2004; Ishihara et al., 2006), adzuki bean Vigna angularis (Hanafy et al., 2006) and Arabidopsis. A mutationbreeding approach has been used to produce tryptophanaccumulating rice by gene targeting mediated mutagenesis of OASA2-an a-subunit of anthranilate synthase (Saika et al., 2011). Transgenic rice plants were generated successfully harboring OASA2 with S126F/L530D, Y367A/L530D, and Y367A mutations. The generated plants possessed 230- fold higher level of tryptophan without any apparent morphological or developmental changes in the plant. Mutant gene Mtr1 (mtr1-D) encodes a rice prephenate dehydratase with a point mutation in the protein regulatory section. Yamada et al. (2008) showed that this mutant gene encoding an altered phenylalanine biosynthetic enzyme results in the accumulation of phenylalanine and tryptophan when introduced in rice callus.

\section{MANIPULATION OF CYSTEINE AND METHIONINE CONTENT}

The Sulfur amino acid composition has a decisive effect on seed protein quality. Methionine, homocysteine, cysteine and taurine are the four common sulfur-containing amino acids, but only methionine and cysteine are incorporated into proteins. Sulfurrich protein from sunflower seed albumin (SSA) was identified and introduced in rice to alter cysteine and methionine contents in the grain. Despite the increase in total protein content in the transgenic plants, an analysis of $7 \%$ of total seed protein of transgenic rice grains showed very little change in the amount of total sulfur or organic sulfur as compared to the untransformed rice grains (Hagan et al., 2003). Methionine and cysteine levels were increased in transgenic rice by $E$. coli serine acetyltransferase isoform $(E c S A T)$. Here cysteine, glutathione, free methionine and methionine content were elevated 2. 4-, 2-, 1. 4-, and 4.8fold respectively. Moreover, the transgenic rice lines had $\sim 2$ fold higher isoleucine, leucine and valine contents indicating potential alteration of methionine to isoleucine thus enhancing the nutritive value of rice (Nguyen et al., 2012).

\section{MANIPULATION OF OTHER PROTEIN CONTENT}

Glycosylated phaseolin, the main reserve globulin of common bean seeds is targeted to the vacuole and enclosed into the protein body (Bollini and Chrispeels, 1978). Since the overall lysine (3.4\%) content in rice seeds makes it the first limiting amino acid, the bean $\beta$-phaseolin, with comparatively elevated lysine content $(6.0 \%)$, was introduced into transgenic rice to increase the nutritional quality of grains (Zheng et al., 1995). The authors reported the biochemical, genetic and subcellular localization studies of the common bean phaseolin in the endosperms of transgenic rice which revealed the $4 \%$ phaseolin content in total rice endosperm protein with a positive gene dosage effect. Nutrition quality of rice is greatly affected by grain protein content (GPC). It was reported that qGPC-1 and qGPC-10, two stable quantitative trait loci are controlling GPC in a mapping population derived from the crossing of japonica and indica rice cultivars (Yang et al., 2019). Map-based cloning reveals that the gene encoding a glutelin type-A2 precursor is the key gene underlying qGPC-10 which functions as a positive regulator of grain protein content and is linked to the rice grain quality (Yang et al., 2019). Furthermore, it was evident that the single nucleotide protein present in the promoter of OSGluA2 is associated with grain protein content diversity (Yang et al., 2019).

A list of efforts attempted for enhancement of proteins and amino acid contents in rice has been presented in Table 4. 
TABLE 4 | Enhancement of proteins and amino acid contents in rice through transgenic method.

\begin{tabular}{|c|c|c|c|}
\hline \multicolumn{4}{|l|}{ Proteins and amino acids } \\
\hline Element type & Gene details & Sources & References \\
\hline Tryptophan & Anthranilate synthase, OASA2 & Rice & Wakasa et al., 2006; Saika et al., 2011 \\
\hline Lysine & $\begin{array}{l}\text { Enhancement of lysine content through recombinant tRNA } \\
\text { (lysine), Beta-Phaseolin with Lysine, aspartate kinase and } \\
\text { dihydrodipicolinate synthase, lysine-rich binding protein } \\
\text { accumulation, LRP, RLRH1, and } \mathrm{RLRH} 2\end{array}$ & $\begin{array}{l}\text { Rice, Bacteria, } \\
\text { Psophocarpus } \\
\text { tetragonolobus }\end{array}$ & $\begin{array}{l}\text { Zheng et al., 1995; Wu and Chen, } \\
\text { 2003; Kawakatsu et al., 2010; Wong } \\
\text { et al., 2015; Liu et al., 2016; Yang et al., } \\
2016\end{array}$ \\
\hline Methionine and cysteine & Serine acetyltransferase, Sunflower seed albumin & E. coli, Sunflower & Hagan et al., 2003; Nguyen et al., 2012 \\
\hline $\begin{array}{l}\text { Threonine, lysine, total } \\
\text { amino acids, and crude } \\
\text { protein }\end{array}$ & lysine (K)/threonine (T) motif (TKTKK1 and TKTKK2) & Rice & Jiang et al., 2016 \\
\hline $\begin{array}{l}\text { Total protein and essential } \\
\text { amino acids }\end{array}$ & Seed albumin (AmA1) & $\begin{array}{l}\text { Amaranthus } \\
\text { hypochondriacus }\end{array}$ & Xu et al., 2017 \\
\hline $\begin{array}{l}\text { Phenylalanine and } \\
\text { tryptophan }\end{array}$ & Phenylalanine biosynthetic enzyme & Rice & Yamada et al., 2008 \\
\hline
\end{tabular}

\section{MANIPULATION OF STARCH CONTENT}

Starch-rich rice is a major diet of most of the world population. Over 2000 million populace in Asia intake more than $60 \%$ of their daily calories from rice (FAO, 2004). High amylose content in grains is a resource of resistant starch (Jiang et al., 2010). Studies have been shown that resistant starch has a protective effect against colorectal cancer in humans, pigs and rats (Phillips et al., 1995; Hasjim et al., 2010; Brites et al., 2011; Regmi et al., 2011). High amylose content also has a positive effect in some other health conditions like the development of non-reversible insulin resistance, depresses plasma total lipid, triacylglycerol and cholesterol concentrations (Lopez et al., 2001; Cheng and Lai, 2000; Fuentes-Zaragoza et al., 2011). Zhu et al. (2012) generated transgenic indica rice plants with high amylase (64.8\%) content and high resistance through complete inhibition of the expression of two starch branching enzyme named SBEI and SBEIIb.

Transgenic grain feeding test on a rat showed a significant decrease in body weight gain, lowered fecal $\mathrm{pH}$, increased fecal mass, increased fecal moisture and increased short-chain fatty acids. Zhu et al. (2012) also revealed that transgenic high-amylose rice possessed a positive effect in lowering the level of blood glucose in diabetic rats.

\section{MANIPULATION AT MICRONUTRIENT LEVEL}

Micronutrient deficiency (MND) is a very common phenomenon of human health worldwide. The term "hidden hunger" is applied to designate the inadequacy of key micronutrients in the human daily diet. Inadequacy of micronutrient causes various diseases such as blindness, anemia, growth retardation, birth effects, and poor development of mental health (Howson et al., 1998; Oakley et al., 2004; Darnton-Hill et al., 2005). Morbidity and mortality through infection are also the effects of MND in various cases (Singhal and Austin, 2002; Black, 2003). Fe, Zn, Cu, and Mn are essential elements for the growth of living organisms as they are the important co-factors for many enzymes.
Rice is not considered as a high source of micronutrients in polished/edible form. Carbohydrates account for almost $90 \%$ of total dry matter in rice endosperm. Moreover, aleurone layer is oil-rich and hence removed or else it makes rice seed rancid upon storage. Essential micronutrients were removed during such processing of milling. Any enhancement in micronutrient content has a significant effect on human nutrition and health (Gregorio, 2002). A small amount of micronutrients (measured by plasma-optical emission spectrometry or ICP-OES) are present in the aleurone layer/bran of rice (Molina et al., 2019). As a consequence, over the last few years, several initiatives were taken to enhance some vital micronutrients such as vitamin A, iron, zinc, iodine and folate in rice through biofortification (Table 5; Impa et al., 2013; Swamy et al., 2016). Micronutrient enriched rice were developed either through traditional plant breeding or genetic engineering to combat the most vulnerable people such as resource-poor women, infants and children with deficiency diseases (Welch and Graham, 2004). Plants absorb minerals from the surrounding soil to meet their necessity rather than synthesizing them de novo. The Genetic engineering approach had been taken to enhance the essential micronutrients especially zinc and iron and vitamin A in rice. The transgenic approach increased nutrient content by enhancing the ability to uptake and translocation through the modulation of different ion transporters. Some anti-nutrient factors like phytic acids were reduced by gene insertion.

\section{MANIPULATION OF $\beta$-CAROTENE CONTENT}

Rice endosperm does not contain beta-carotene, thus vitamin A deficiency is common in the countries where rice is the staple food and meets the majority of the nutritional requirements of human health. Vitamin A or $\beta$-carotene is an essential micronutrient in a daily diet. Its' deficiency cause a number of diseases such as night blindness, xerophthalmia and keratomalacia (Ye et al., 2000). Rice is devoid of provitamin A ( $\beta$-carotene) or $\mathrm{C}_{40}$ carotenoid precursors in the endosperm. 
TABLE 5 | Enhancement of micronutrients in rice through transgenic methods.

\begin{tabular}{|c|c|c|c|}
\hline \multicolumn{4}{|c|}{ Micronutrients } \\
\hline Element type & Gene details & Sources & References \\
\hline Iron (Fe) and zinc (Zn) & $\begin{array}{l}\text { Iron and zinc content elevation via ferritin, NAS, IDS3, } \\
\text { OsVIT, IRT1, OsGluB1 pro-SoyferH1 gene }\end{array}$ & $\begin{array}{l}\text { Soybean, Maize, Rice and } \\
\text { Barley }\end{array}$ & $\begin{array}{l}\text { Goto et al., 1999; Lucca et al., 2001; } \\
\text { Vasconcelos et al., 2003; Qu et al., 2005; } \\
\text { Suzuki et al., 2008; Masuda et al., 2009; Lee } \\
\text { et al., 2009b, 2012; Paul et al., 2012; Oliva } \\
\text { et al., 2013; Trijatmiko et al., } 2016\end{array}$ \\
\hline Folate & $\begin{array}{l}\text { Enhancement of folate content by AtGTPCHI, AtADCS, } \\
\text { AtDHFS, AtFPGS, GTPCHI, ADCS, pterin and } \\
\text { aminobenzoate }\end{array}$ & Arabidopsis & $\begin{array}{l}\text { Storozhenko et al., 2007; Dong et al., 2014; } \\
\text { Blancquaert et al., } 2015\end{array}$ \\
\hline$\beta$-carotene & Phytoene synthase, crtl, locopene $\beta$ cyclase, psy gene & $\begin{array}{l}\text { Narcissus pseudonarcissus } \\
\text { (daffodil),Erwinia uredovora, }\end{array}$ & $\begin{array}{l}\text { Burkhardt et al., 1997; Ye et al., 2000; Tang } \\
\text { et al., } 2009\end{array}$ \\
\hline $\begin{array}{l}\text { Iron }(\mathrm{Fe}), \text { zinc }(\mathrm{Zn}) \text { and } \\
\text { beta carotene }\end{array}$ & AtNAS1, PvFERRITIN, CRTI, ZmPSY & $\begin{array}{l}\text { Arabidopsis, Bean, Bacteria } \\
\text { and Maize }\end{array}$ & Singh et al., 2017 \\
\hline Phytic acid & $\begin{array}{l}\text { Lowering phytic acid content via lowering OsINO1 gene } \\
\text { using Olesin18 promoter and Mutants with low PA (ipa) }\end{array}$ & Rice & Larson et al., 2000; Kuwano et al., 2009 \\
\hline
\end{tabular}

As an indispensable food crop it was essential to make rice more nutritious in terms of $\beta$-carotene. Burkhardt et al. (1997) designed an experiment which made rice endosperm capable of synthesizing $\beta$-carotene. After a thorough investigation using $\left[{ }^{14} \mathrm{C}\right]$ labeled substrate, it was found that rice endosperm has geranyl geranyl diphosphate (GGPP) $\left(\mathrm{C}_{20}\right.$ general isoprenoid precursor necessary for $\mathrm{C}_{40}$ carotenoid biosynthesis). The first specific enzyme responsible for $\beta$-carotene synthesis in plants is phytoene synthase which condenses two molecules of GGPP. Taking the advantage of presence of GGPP in rice endosperm, a japonica variety of rice Taipei 309 was transformed by micro projectile bombardment with a cDNA coded for phytoene synthase from Daffodil or Narcissus pseudonarcissus. It was a significant achievement and first attempt to enable rice embryo for the synthesis of $\sim 2 \mu \mathrm{g}$ of $\beta$-carotene per gram dry seed weight which is enough for young children. Ye et al. (2000) reported invention of Golden rice, which is known as prototype of GR1. They took psy (phytoene synthase) gene from daffodil and two other genes crtI (phytoene desaturase) and lcy (lycopene cyclase) from E. uredovora. Later studies (Schaub et al., 2005) showed that lcy is not required for beta-carotene biosynthesis in Golden rice. This is an important breakthrough where a biosynthetic pathway was established in rice endosperm and gave the rice grains a characteristic yellow color and named it "Golden Rice." Phytoene synthase ( $p s y$ ) from daffodil, however, has a limitation for the synthesis of a higher level of carotenoids which was a limiting factor for desirable accumulation of $\beta$ carotene. Subsequently, Paine et al. (2005) replaced the daffodil psy by its homolog from maize and thus improved the nutritional value of "Golden rice" by increasing the pro-vitamin A content by $\sim 23$-fold higher which was as maximum as $\sim 37 \mu \mathrm{g} / \mathrm{g}$ in rice endosperm. They identified the limiting step of $\beta$ carotene accumulation in some wild type tissues of different rice cultivars. Apsy gene from maize was recognized which increased the carotenoid accumulation higher than previous Golden Rice and termed this as "Golden rice 2." Golden rice is now considered as an effective source of vitamin A
(Tang et al., 2009). After several years of its production Golden rice has become very popular and incorporated into many breeding programs in Asia (Potrykus, 2008). Compositional assessment of Golden Rice 2 event (GR2E) was achieved on the grain, straw and bran samples of GR2E and control rice (PSBRc82) collected from 4 locations in Phillipines. The level of $\beta$ carotene was the only factor difference between two types of rice grains. GR2E can contribute up to $57-113 \%$ provitamin A for the preschool students in Bangladesh and Phillipines (Swamy et al., 2019).

Astaxanthin is a ketocarotenoid which is red in color with high antioxidant activity. Though, Most of the higher plants do not produce astaxanthin. Zhu et al. (2018) reported that bioengineering of astaxanthin biosynthetic pathway genes (sPaCrtI, sZmPSY1, sHpBHY, and sCrBKT, encode the enzymes phytoene desaturase, phytoene synthase, b-carotene hydroxylase, and b-carotene ketolase, respectively) could produce rice grains enriched with endospermic astaxanthin and had higher antioxidant activity. Tian et al. (2019) successfully enhanced biosynthesis of carotenoid in rice endosperm through metabolic engineering They showed that the expression of three chemically synthesized genes, i.e., tHMG1, ZmPSY1, and PaCRTI, considerably enhanced the amount of carotenoids in the endosperm of rice by improving the flux through the mevalonate route.

\section{MANIPULATION OF ANTHOCYANIN CONTENT}

Anthocyanins contain high antioxidant activities. It has been reported that engineering of eight anthocyanin related genes (two from maize which are regulatory genes and six from Coleus which are structural genes) with endosperm specific promoters produced a novel biofortified germplasm called "Purple Endosperm Rice" (Zhu et al., 2017). It has been proved that this novel rice endosperm has a high level of anthocyanin and antioxidant activity (Zhu et al., 2017). 


\section{MANIPULATION OF FOLATE CONTENT}

The deficiency of folate (vitamin $\mathrm{B}_{9}$ ) is a worldwide health problem as this water-soluble vitamin cannot be synthesized de novo by the human body. Only plants and microorganisms can synthesize folate. Hence humans have to depend exclusively on plant diet for folate supplements (Bekaert et al., 2008; Blancquaert et al., 2015). Inadequacy of folate can cause serious health issues such as neural tube defects (NTD), megaloblastic anemia, different ranges of cancer, some neurodegenerative disorder like Alzheimer's disease, major depressive disorders (MDD) and a higher risk of cardiovascular and coronary diseases (Geisel, 2003; $\mathrm{Li}$ et al., 2003; Iyer and Tomar, 2009). The daily requirement of folate varies from 400 to $600 \mu \mathrm{g}$ in men, women and pregnant women ${ }^{1}$. As an important staple food for all over the world rice lacks the required amount of folate to meet the daily diet. The concentration of folate was enhanced in rice by overexpressing two genes (pterin and aminobenzoate branches of folate biosynthetic pathway) encoding two enzymes from folate biosynthesis of Arabidopsis thaliana under control of a rice endosperm specific promoter (Storozhenko et al., 2007). These genetically modified rice lines were able to enhance folate level $\sim 100$ times higher compared to the wild type plant thus recording about four-fold higher concentrations than the recommended daily intake (RDI) for folate ${ }^{2}$. In another study, the evaluation was done for each step of folate biosynthesis pathway in a japonica variety of rice (kitaake) by overexpression of two genes from Arabidopsis thaliana coding for GTP cyclohydrolase I and amino deoxychorismate synthase in the branches of pterin and para-aminobenzoate which affected the significant increase of folate content in rice endosperm (Dong et al., 2014).

\section{MANIPULATION OF IRON AND ZINC CONTENT}

Deficiency of iron is most common in the human population which leads to some important diseases such as anemia, impaired development and growth in preschool children and pregnant woman (World Health Organization [WHO], 2017). This crucial element plays a key role in electron transfer in both photosynthesis and respiration (Inoue et al., 2009; Ludwig and Slamet-Loedin, 2019). Biofortification of rice involves iron uptake, translocation and storage (Takagi et al., 1984). An iron storage protein "ferritin" is prevailing in most of the organisms including plants (Theil, 1987; Majumder et al., 2019). Soybean ferritin genes (SoyferH1 and SoyferH2) were utilized for iron biofortification in rice as it was suggested that soybean ferritin iron complex is easily absorbed by the human intestine (Theil, 1987; Kok et al., 2018). The whole coding sequence of the soybean ferritin gene was introduced in rice (Kitake variety) by Agrobacterium mediated transformation (Goto et al., 1999). Rice endosperm specific promoters like globulin $(O s G l b)$ and glutelin $(O s G l u B 1)$ were used to enhance iron content in rice

\footnotetext{
${ }^{1}$ http://ods.od.nih.gov/Health_Information/Dietary_Reference_Intakes.aspx

${ }^{2}$ http://ods.od.nih.gov/factsheets/Folate-Health Professional/
}

varieties which was able to increase nearly 3-3.7-fold iron content (Vasconcelos et al., 2003; Qu et al., 2005; Paul et al., 2012). Rice endosperm specific GlutelinA2 (OsGluA2) promoter was utilized to enhance Fe content in Pusa-sugandhi II (Paul et al., 2012). Overexpression of rice ferritin (Osfer2) increased 2.09-fold iron and 1.37-fold zinc in transgenic rice endosperm (Paul et al., 2012). IR68144 is a high iron rice variety (3.7-fold increased iron in polished grain) developed through conventional cross breeding between IR72 and Zawa Bonday (Gregorio et al., 2000). Vasconcelos et al. (2003) used IR68144 in transformation with ferritin genes from different sources as a recipient. IR68144 variety was also used for breeding with high yielding variety Swarna which increased 2.54-fold iron and 1.54-fold zinc than the wild type Swarna (Paul et al., 2012). Uptake of iron is based on two strategic types in plants, i.e., (1) reduction and (2) chelation (Ishimaru et al., 2006; Wirth et al., 2009; Kok et al., 2018). Under low iron conditions, graminaceous plants uptake iron by chelation based strategy where $\mathrm{Fe}^{3+}$ transports from rhizosphere to the roots of plants by producing phytosiderophores. However, rice uptake iron by the combined strategy of both chelation and the reduction. Under reduction based method $\mathrm{Fe}^{3+}$ is reduced to $\mathrm{Fe}^{2+}$ before going to absorb by plants. Usually, non-gramenaceous plants release protons to the surrounding environment which is the cause of low $\mathrm{pH}$, help to the reduction of iron (Kok et al., 2018). During chelation based method nicotinamine synthase (NAS) is the principal enzyme for the release of phytosiderophores under iron deficit condition in rice plants. Transporter of mugeniec acid (MA) or TOM1 supports to form the phytosiderophores (Huguchi et al., 1999; Nozoye et al., 2011). But iron uptake in rice performed by the combined process of reduction and chelation (Kim and Guerinot, 2007). Since MA has a higher affinity toward $\mathrm{Fe}^{3+}$, it forms iron complexes and transported in the roots via yellow stripe 1 transporters or YSL1. Hence keeping this view in mind scientists overexpressed genes with the involvement of MA for biofortification of iron content in rice such as overexpression of NAS genes. Overexpression of three NAS genes (OsNAS1, OsNAS2, and OsNAS3) increased iron content in rice (Table 5; Johnson et al., 2011; Lee et al., 2009a, 2012; Kok et al., 2018). Altered expression of OsYSL2 increased 4.4-fold iron content in rice grains (Ishimaru et al., 2010). Moreover, in barley iron deficiency clone no.2 (IDS2) and no.3 (IDS3) performed an important role to tackle iron inadequacy.IDS genes activate mugineic acids which are highly expressed in roots during the iron deficit condition. IDS3 rice lines exhibited 1.4- and 1.3fold elevated iron content in polished and brown rice grains respectively in both iron positive and negative soil (Masuda et al., 2008; Suzuki et al., 2008). Accumulation of zinc and iron content increased by knockdown of OsVIT1 and OsVIT2 (vacuolar iron transporter genes). This approach enhanced 1.4-fold iron in transgenic rice grains (Bashir et al., 2013). Another investigation made by Masuda et al. (2013b) where they introduced SoyferH2 gene under the control of two promoters like OsGluB1 and OsGlband also with three barley genes (HvNAS1, HvNAAT-A, $H v N A A T-B)$ encoding for the biosynthesis of mugineic acid in Tsukino Hikari rice cultivar. They found 4-fold increases in iron content in polished grains. 
Zinc is another major micronutrient in rice act as a cofactor for $\sim 300$ enzymes in the metabolism of lipids, proteins, carbohydrates and nucleic acids (Swamy et al., 2016). Malnutrition due to zinc is the major problem in the areas where polished rice is staple food (Rao et al., 2020). An appropriate amount of zinc is necessary for maintaining a healthy life. $\sim 7-13 \mathrm{mg}$ zinc per day is needed for adults [Department of Health (United Kingdom) 1991; Institute of Medicine Food and Nutrition Board IMFNB 2001]. Zinc deficiency causes loss of appetite, retardation of growth, impaired immune function, loss of hair and weight, diarrhea, skin and eye lesions, delayed healing of wounds and mental lethargy (Prasad, 2004). For the last few years, efforts on zinc biofortification have been made to obtain high-zinc rice. Some candidate genes families were identified for their involvement in zinc and iron uptake such as OsZIPs, OsIRTs, OsNASs, and OsNRAMPs. Such investigations have been made to amplify zinc content in addition to iron by enhancing zinc uptake efficiency or unhindered transport in different plant tissues specifically during the grain filling stage in rice (Ishimaru et al., 2005, 2007, 2011; Chandel et al., 2010; Yamaji et al., 2013; Sasaki et al., 2014; Swamy et al., 2016). While reviewing the internal translocation of zinc in plant tissues it was observed by some scientists that variation of concentration of zinc uptake by root can cause a problem while passing zinc from vegetative tissues to grain (Stomph et al., 2014; Yin et al., 2016). Such studies based on zinc loading from vegetative tissues to rice endosperm remained very useful for the biofortification of zinc (Jiang et al., 2007; Wu et al., 2010). Several ZIP family metal transporter genes are upregulated under zinc deficient conditions in rice (Ramesh et al., 2003; Lee and An, 2009; Tan et al., 2015). OsYSL2 gene overexpression caused 4-fold increases in iron and zinc content in rice (Ishimaru et al., 2010; Masuda et al., 2013a). Overexpression of NAS family genes enhanced iron and zinc concentration (Johnson et al., 2011; Lee et al., 2011). It was found that overexpression of OsIRT from rice and MxIRT from apple caused iron and zinc content enhancement in GM rice endosperm (Lee and An, 2009; Tan et al., 2015).

An initiative was taken by HarvestPlus in collaboration with International Rice Research Institute (IRRI) for better nutrition of crops to minimize micronutrient malnutrition by improving micronutrient content in staple crops. In 2013 they released a zinc biofortified rice variety in Bangladesh. The biofortified rice variety can meet $60 \%$ of daily zinc needs (Goldstein, 2018). Similarly in India the collaboration with the Department of Biotechnology (DBT), Indian Council of Agricultural Research (ICAR) and Indian Institute of Rice Research (IIRR) helped for the release of zinc biofortified rice varieties. Ninety-nine rice genotypes and 344 lines from different mapping populations have met the target ( $\geq 28 \mathrm{mg} / \mathrm{kg}$ of zinc). After the characterization of germplasm some zinc biofortified rice in polished grains has been released in India (Rao et al., 2020). DRR Dhan 45 is one of the released varieties with double the content of IR64 (22.6-24.0 ppm in polished grains) (accessed on 14 April 2019) ${ }^{3}$. Another drive made by Trijatmiko et al. (2016) where selected transgenic rice lines were field evaluated in two countries for biofortified iron

${ }^{3}$ https://icar.org.in/node/6293 and zinc content. Single locus insertion was observed for rice nicotinamine synthase (OsNAS2) and soybean ferritin (SferH-1) genes without any modified grain quality or any reduction in yield (Trijatmiko et al., 2016).

Besides iron content, $\mathrm{Zn}$ and $\mathrm{Cd}$ are also elevated in the mature seeds. As OsIRT1 is an ion transporter involve in metal homeostasis (Lee and An, 2009). Three approaches (ferritin gene from Phaseolus vulgaris, phytase from Aspergillus fumigatus and cysteine peptides) were taken by Lucca et al. (2001) to increase iron content in transgenic rice and this attempt increased iron level about 130-fold. Iron transporter I and Nicotinamine synthase from Arabidopsis and ferritin gene from bean were introduced in rice to increase iron level in both polished and unpolished grains up to $10.46 \mu \mathrm{g} / \mathrm{g}$ dry weight.

\section{BIOFORTIFICATION OF MULTIPLE MICRONUTRIENTS}

A new strategy was adopted by Singh et al. (2017) to enhance iron, zinc and $\beta$-carotene in a single locus of rice endosperm. A transgenic rice line which expressed Arabidopsis nicotianamine synthase1 (AtNAS1), bean FERRITIN (PvFERRITIN), bacterial CAROTENE DESATURASE (CRTI), and maize PHYTOENE SYNTHASE (ZmPSY) showed enhanced iron, zinc and $\beta$-carotene level. A Significant amount of iron, zinc and $\beta$-carotene were increased in the endosperm. Zhu et al. (2019) discussed the latest advancement in the area of synthetic metabolic engineering of plants, exclusively the method of multigene stacking through considering genes from different/same metabolic pathways. Here, the aim was to enhance nutrient content and bioactive elements in the plants which will definitely meet the nutritional requirements of humans.

\section{MANIPULATION OF TRANSPORTERS}

Rice has a distinctive root structure and mineral uptake system (Sasaki et al., 2016; Huang et al., 2020). The supply of mineral elements is mediated via transporters present in the nodal region of the plant (Yamaji and Ma, 2017). Several transporters involved in mineral nutrients uptake and their distribution have been identified in the last decade (Mitani-Ueno et al., 2018). Through the manipulation of $\mathrm{Fe}$ transporter, several efforts have been made to increase the concentration of $\mathrm{Zn}$ and $\mathrm{Fe}$ in rice grain (Masuda et al., 2012, 2009). It was found that introduction of rice $\mathrm{Mn}-\mathrm{NA}$ transporter with barley $\mathrm{NA}^{++}$synthase gene and soybean Ferritin gene resulted in 4.4-fold Fe increase and 1.6fold $\mathrm{Zn}$ increase in transgenic rice grain (Masuda et al., 2012). Che et al. (2019) reported that OsVMT knockout resulted in increased $\mathrm{Zn}$ and Fe level in rice grain. Yamaji et al. (2017) reported that novel plasma membrane-localized transporter gene (OsSPDT) knockout resulted in $\sim 20 \%$ decrease of phytic acid in rice grains. Additionally, Knockout of OsSPDT also resulted in an increased level of $\mathrm{Zn}$ and Fe. Overexpression of rice peptide transporter NRT1 responsible for nitrate transport resulted in improved Se accumulation in rice grain (Zhang et al., 2019). 
$\mathrm{Cd}$ and As accumulation is toxic to the plant. Transgenic approaches have been adopted to develop knockout rice plants using OsNramp5, OsHMA2, and OsCd1 genes for reduction of the level of $\mathrm{Cd}$ and with the negative effect on grain yield (Ishikawa et al., 2012; Sasaki et al., 2012; Yamaji et al., 2013; Tang et al., 2017). On the other hand, Shao et al. (2018) showed that overexpreesion of OsHMA3 resulted in a significant reduction of $\mathrm{Cd}$ in rice without yield penalty. Overexpression of OsNIP1 and OsNIP3 in rice showed decreased As (arsenic) accumulation in the grain (Sun et al., 2018). Furthermore, As accumulation has been reduced by the targeted overexpression of OsABCC1 in the internode phloem and root cortical cells (Deng et al., 2018).

\section{LOWERING PHYTIC ACID CONTENT}

Myo -inositol hexa phosphateor phytic acid (PA) is the principal storage form of phosphorus $(\mathrm{P})$ in the cereal grains. PA is considered as the most abundant inositol phosphate and chelates metal ions such as calcium, magnesium, potassium, zinc and iron to form phytate or phytin. Cereals are very rich in phytic acid content. Rice contains $8.7 \% \mathrm{PA}$ in their bran (Lehrfeld, 1994; Gupta et al., 2015). This insoluble salt prevents the absorption of important nutrients in the intestine of human beings which leads to the deficiency of micronutrients (Raboy, 2000; Mitchikpe et al., 2008; Perera et al., 2018). Hence, different methods of biofortification had been applied to lower down the phytic acid levels in rice to increase the absorption rate of iron and zinc (Hurrell et al., 2003). Mutants with low PA content (lpa) were characterized and developed which showed higher micronutrient content in the seed. $45 \%$ reduction of PA was seen due to a non-lethal mutant in Kaybonnet rice variety (Larson et al., 2000). Initiatives had been taken to lower down the level of OsINO1 gene expression which automatically reduced PA using Olesin18 (Ole18) promoters (Kuwano et al., 2009). As phytate is not digested by animal system due to lack of phytase enzyme, low phytate rice was generated very recently by overexpressing $E$. coli appA gene which enhanced inorganic $\mathrm{P}$ level by 4 -fold along with zinc and iron. The gene $a p p A$ encoded AppA protein which is non-glycosylated and periplasmic (Bhattacharya et al., 2019).

\section{CONVENTIONAL AND MOLECULAR BREEDING STRATEGIES FOR THE IMPROVEMENT OF NUTRIENTS}

To create superior cultivars of rice with higher nutritional value, scientists of IRRI and the University of Adelaide collaborated for documenting the zinc and iron content of several rice varieties (Graham et al., 1999). This work resulted in the identification of rice varieties with high iron and zinc content. The initial focus is on successfully breeding a rice variety containing higher absolute mineral content. Graham et al. (2007) tried to gain higher bioavailability by three possible ways (a) raise the percentage of bio-availability (by declining material that inhibits uptake of nutrient), (b) raise the nutrient concentration in the grain, and (c) a mixture of these two methods.

The breeding strategy involves screening of rice lines contain high amount of micronutrients necessary for the human population. Numerous works have been done based on the finding of rice germplasm with high amount of micronutrients (Anandan et al., 2011; Anuradha et al., 2012; Babu et al., 2012). It seems that major mineral content such as $\mathrm{Fe}, \mathrm{Zn}, \mathrm{Cu}, \mathrm{Mn}$ was higher in traditional rice varieties in comparison to modern high yielding varieties (Anandan et al., 2011). Highest grain iron and zinc concentration were identified in some aromatic rice varieties (Jalmagna, Zuchem, and XuaBueNuo). Range of iron and zinc concentration in those aromatic rice cultivars were $\sim 18-22 \mu \mathrm{g} / \mathrm{g}$ and $\sim 24-35 \mu \mathrm{g} / \mathrm{g}$ respectively (Graham et al., 1999). Agronomic traits are studied and manipulated by QTL mapping for several years (Jeong et al., 2020). Genes responsible for micronutrients especially iron, zinc, and other essential micronutrient content in rice were mapped through QTL which will help in future breeding program. QTLs used in breeding programs to increase nutrient contents are tabulated in Table 6. Five QTL had been mapped in different chromosomes for iron and zinc concentration in unpolished/brown rice grains (Anuradha et al., 2012). Genome wide mapping was done from the cross of Madhukar $\times$ Swarna variety that helps in mapping 14 QTLs for iron and zinc content in unpolished rice grains (Agarwal et al., 2014). SNP and SSR markers were used in MAS to enhance zinc and iron content. Recently double-haploid (DH) mapping populations of rice were evaluated for higher grain zinc in rice (Swamy et al., 2018a). Swamy et al. (2018a) mapped QTLs for grain micronutrients in addition to yield potential and QTL $x$ QTL interconnections. Some candidate genes associated with rice grain zinc (OsNRAMP, OsNAS, OsZIP, OsYSL, OsFER, and OsZIFL family) were identified in association with these QTLs. QTLs for other mineral elements were also mapped (Swamy et al., 2018a). Another rice DH population was used (Korean japonica cultivars) to identify the major effect of QTLs related to grain iron and zinc content (Jeong et al., 2020), where the candidate genes were also analyzed. Two double haploid rice lines were used for QTL analysis for 13 grain elements (Descalsota-Empleo et al., 2019). Lee et al. (2020) analyzed and produced a double haploid by crossing between an indica (93-11) and japonica (Milyang 352) rice cultivars. They mapped two co-localized QTL such as $q \mathrm{Fe} 3$ 1 and qZn3-1 for iron and zinc respectively which will be useful for future nutrient-rich rice (Lee et al., 2020). Double haploid rice lines were investigated by Calayugan et al. (2020) by crossing IR05F102 x IR69428 for high grain Zn and Fe. Here, they found 5 QTL related to these micronutrients. A further study was made by Swamy et al. (2018b) which showed two $\mathrm{BC}_{2} \mathrm{~F}_{3}$ mapping populations, the crosses between $O$. sativa (Swarna variety) and O. nivara, QTLs were mapped for $\mathrm{Zn}$ and $\mathrm{Fe}$ concentration in grains. A large population with 485 germplasm lines was assessed for the association mapping of $\mathrm{Zn}$ and $\mathrm{Fe}$ content in rice grains. In addition to this, iron and zinc controlling linkage disequilibrium QTL mapping was performed which were very useful for micronutrient rich milled rice (Pradhan et al., 2020). Cereal grains are one of the major 
TABLE 6 | QTLs identified for nutrient enhancement in rice (Oryza sativa).

\begin{tabular}{|c|c|c|}
\hline Traits & Respective QTL & References \\
\hline Zinc $(Z n)$ & $\begin{array}{l}\text { qZN-5, qZN-7, qSZn2, qSZn12, qZn7, qZn3.1, qZn7.1, qZn7.2, qZn7.3, } \\
q Z n 12.1, q Z n 4, q Z n 6, q Z n 1-1, q Z n 12-1, q Z n 5-1, q Z n 8-1, q Z n 12-1, q Z n 2.1, \\
q Z n 2.1, q Z n 3.1, q Z n 6.1, q Z n 6.2, q Z n 8.1, q Z n 11.1, q Z n 12.1, q Z n 12.2, q Z n 2.2, \\
q Z n 8.3, q Z n 12.3, q Z n 3.1, q Z n 7, q Z n 8.3, q Z n 3-1, q Z n 1.1, q Z n 5.1, q Z n 9.1, \\
q Z n 12.1, q Z n 1.1, q Z n 6.1, q Z n 6.2, q Z n 2-1, q Z n 2-2, q Z n 5, q Z n 10, q Z n 2.1, \\
q Z n 3.1, q Z n 5.1, q Z n 5.2, q Z n 7.1, q Z n 9.1, q Z n 11.1, q Z n 1.1, q Z n 2.1, q Z n 3.1, \\
q Z n 3.2, q Z n 5.1, q Z n 6.1, q Z n 8.1, q Z n 8.2, q Z n 9.1, q Z n 12.1\end{array}$ & $\begin{array}{l}\text { Lu et al., 2008; Garcia-Oliveira et al., 2009; Ishikawa } \\
\text { et al., 2010; Zhang et al., 2011; Anuradha et al., 2012; } \\
\text { Jin et al., 2013; Swamy et al., 2018a; Swamy et al., } \\
\text { 2018b; Dixit et al., 2019; Descalsota-Empleo et al., } \\
\text { 2019; Calayugan et al., 2020; Lee et al., 2020; Pradhan } \\
\text { et al., } 2020\end{array}$ \\
\hline Iron $(\mathrm{Fe})$ & $\begin{array}{l}\text { qFE-1, qFE-9, qGFe4, qSFe1, qSFe12, qFe1, qFe3, qFe6, qFe2-1, qFe9-1, } \\
\text { qFe4.1, qFe3.3, qFe7.3, Fe8.1, qFe12.2, qFe3-1, qFe9.1, qFe12.1, qFe1.1, } \\
\text { qFe1.2, qFe6.1, qFe6.2, qFe5, qK6.1, qFe2.2, qFe3.1, qFe4.1., qFe6.1, } \\
\text { qFe8.1, qFe11.2, qFe11.3, qFe12.1, }\end{array}$ & $\begin{array}{l}\text { Stangoulis et al., 2007; Lu et al., 2008; Garcia-Oliveira } \\
\text { et al., 2009; Ishikawa et al., 2010; Norton et al., 2010; } \\
\text { Jin et al., 2013; Swamy et al., 2018a; Swamy et al., } \\
\text { 2018b; Dixit et al., 2019; Calayugan et al., 2020; Lee } \\
\text { et al., 2020; Pradhan et al., } 2020\end{array}$ \\
\hline Zn and Iron & $q Z n 10, q Z n 2, q Z n 4, q Z n 5, q Z n 6, q Z n 7, q Z n 9$ & Zhang et al., 2014 \\
\hline Manganese (Mn) & $\begin{array}{l}\text { qMn1-1, qMn2-1, qMn3-1, qMn10-1, qMn2.1, qMn2.1, qMn7.1, qMn1.1, } \\
\text { qMn1.2, qMn3.1, qMn3.2, qMn4.1 }\end{array}$ & $\begin{array}{l}\text { Garcia-Oliveira et al., 2009; Swamy et al., 2018a; } \\
\text { Descalsota-Empleo et al., } 2019\end{array}$ \\
\hline Calcium & $\begin{array}{l}\text { qCa1-1, qCa4-1, qCa5-1, qCa9-1, qCa10-1, qCa11-1, qCa12-1, qCa1.1, } \\
\text { qCa1.1, qCa2.1, qСa2.1, qСa3.1, qСa3.2, }\end{array}$ & Garcia-Oliveira et al., 2009; Swamy et al., 2018a \\
\hline Magnesium (Mg) & $\begin{array}{l}\text { qMg1-1, qMg3-1, qMg5-1, qMg9-1, qMg12-1, qMg3.1, qMg3.2, qMg5.1, } \\
\text { qMg8.1, qMg9.1, qMg1.1, qMg7.1, qMg8.1, qMg11.1 }\end{array}$ & $\begin{array}{l}\text { Garcia-Oliveira et al., 2009; Swamy et al., 2018a; } \\
\text { Descalsota-Empleo et al., } 2019\end{array}$ \\
\hline Phosphorus (P) & $\begin{array}{l}q P 1-1, q P 3-1, q P 8-1, q P 9-1, q P 12-1, q P 1.1, q P 2.1, q P 2.2, q P 5.1, q P 6.1 \\
q P 11.1, q P 11.2\end{array}$ & $\begin{array}{l}\text { Garcia-Oliveira et al., 2009; Swamy et al., 2018a; } \\
\text { Descalsota-Empleo et al., } 2019\end{array}$ \\
\hline Potassium (K) & $\begin{array}{l}q K 1-1, q K 4-1, q K 8-1, q K 9-1, q K 2.1, q K 4.1, q K 4.2, q K 5.1, q K 9.1, q K 3.1 \text {, } \\
q K 3.2, q K 3.3, q K 4.1, q K 5.1\end{array}$ & $\begin{array}{l}\text { Garcia-Oliveira et al., 2009; Swamy et al., 2018a; } \\
\text { Descalsota-Empleo et al., } 2019\end{array}$ \\
\hline Boron (B) & $q B 2.1, q B 3.1, q B 4.1, q B 4.2, q B 10.1$ & Swamy et al., 2018a; Descalsota-Empleo et al., 2019 \\
\hline Cobalt (Co) & qCo1.1, qСo3.1, qCo4.1, qCo12.1, qCo7.1, qCo10.1 & Swamy et al., 2018a; Descalsota-Empleo et al., 2019 \\
\hline Copper (Cu) & qCu3.1, qCu4.1, qCu4.2, qCu1.1, qCu1.2, qCu2.1, qCu6.1, qCu8.1 & Swamy et al., 2018a; Descalsota-Empleo et al., 2019 \\
\hline Molybdenum (Mo) & $\begin{array}{l}\text { qMo1.1, qMo1.1, qMo1.2, qMo1.3, qMo1.3, qMo2.1, qMo11.1, qMo12.1, } \\
\text { qMo12.1, qMo12.1, qMo1.1 }\end{array}$ & Swamy et al., 2018a \\
\hline Sodium (Na) & qNa1.1, qNa1.2, qNa7.1, qNa7.2, qNa10.1, qNa3.1, qNa11.1, qNa11.2 & Swamy et al., 2018a; Descalsota-Empleo et al., 2019 \\
\hline Phytate & QTL for phytate & Stangoulis et al., 2007 \\
\hline Grain protein content (GPC) & $\begin{array}{l}\text { QTL for PC (Protein content). qPC1, qPC2, qPC3, qPC6.1, qPC6.2, qPC8, } \\
\text { qPC12.1, qPC1.1, qPC11.1, and qPC11.2, qPC-3, qPC-4, qPC-5, qPC-6 and } \\
\text { qPC-10, qPr1 and qPr7, qPro-8, qPro-9 and qPro-10, qGPC1.1, qSGPC2.1 } \\
\text { and qSGPC7.1 }\end{array}$ & $\begin{array}{l}\text { Tan et al., 2001; Qin et al., 2009; Yu et al., 2009; Zhong } \\
\text { et al., 2011; Yun et al., 2014; Mahender et al., 2016; } \\
\text { Kinoshita et al., 2017; Chattopadhaya et al., } 2019\end{array}$ \\
\hline Amino acid content (AAC) & qAa1, qAa7 & Zhong et al., 2011 \\
\hline Lysine & qAa9, qPC1 & Zhong et al., 2011; Peng et al., 2014 \\
\hline Cys/Leu/lle/Phe & $q A A .10$ & Wang et al., 2008 \\
\hline
\end{tabular}

sources of protein for human food. Hence, quantification of grain protein content (GPC) is essential (Peng et al., 2014). Prolamins and glutelins are the major sub-divisions of protein content in rice (Shewry et al., 1995). For human diet, glutelin have a high nutritive value (Ufaz and Galili, 2008; Zhang et al., 2008). A large number of QTLs associated with GPC has been identified and mapped in milled rice. All amino acids content (AAC) including essential and total AAC were characterized using a population of 190 recombinant inbred lines (RILs) from a cross between Zhenshan97 and Nanyangzhan rice variety (Wang et al., 2008). It was proved that a QTL for AAC, qPC1 encodes a putative amino acid transporter OsAAP6 (Peng et al., 2014). Very recently, another QTL for GPC in rice was mapped in more than one chromosome like $1,2,6,7,10$, and 11 . Three QTLs were identified of which one is responsible for grain protein content ( $q$ GPC1.1) and the other two for single grain protein content ( $q S G P C 2.1$ and qSGPC7.1). Moreover, these QTLs were detected as environmentally stable. A glutelin encoded gene (Os01g0111900) was found to be associated with this QTL, was upregulated during seed development (Chattopadhaya et al., 2019).

\section{AGRONOMIC BIOFORTIFICATION}

Apart from transgenic methods, molecular and conventional breeding approaches, agronomic biofortification is another strategy based on application of optimized fertilizer for nutrient enhancement in rice. Microelements like zinc, iron, copper manganese etc. are generally absorbed from the soil in different plants (Garg et al., 2018). The application of fertilizers in the soil can also meet the deficiency of micronutrients in plants (Graham et al., 2007). Zinc was applied through soil and foliar methods which increased maximum yield with higher $\mathrm{Zn}$ content in rice grains. Furthermore, high $\mathrm{Zn}$ accumulation resulted in higher iron accumulation and loss of phytic acid (Saha et al., 2017). 
Application of nitrogen fertilizer enhanced GPC, $\mathrm{Zn}$ and Fe in brown rice. Different locations altered the elevation of micro and macronutrients in rice by the application of $\mathrm{N}_{2}$ fertilizer (Chandel et al., 2010).

\section{CONCLUSION AND FUTURE PROSPECTIVE}

Rice is a key source of carbohydrate and B vitamins. However, rice consumption as a major food is not sufficient to meet the nutrition requirement for rice eaters in developing countries and most of the people of rice dependent countries experience various forms of undernourished feeding. Agriculture pattern, post-harvest processes and climate conditions have a considerable negative effect on the nutritional quality of rice. Enhancement of rice nutritional value is necessary in developing countries to avoid malnutrition in the coming era. In current era, rice researchers along with rice nutritionists are working together toward optimizing the nutrition level of rice by adopting biotechnological or breeding methods to get new and better varieties and to provide the best to the rice dependent population. Recent progress in rice nutrition enhancement through biotechnology might be capable to ameliorate malnutrition presently experienced. Nutritional value related genes and QTLs will play crucial roles in developing the required genotypes. In current years, considerable efforts have been made in molecular studies on grain amino acid and protein content, glycemic index value, vitamins, minerals and their transporters, phytic acid, phenolic and flavonoid compounds, zinc and iron content. However, more research is needed for the processing of the newly developed nutritionally enhanced varieties. In India, recently released

\section{REFERENCES}

Agarwal, S., Tripura Venkata, V. G., Kotla, A., Mangrauthia, S. K., and Neelamraju, S. (2014). Expression patterns of QTL based and other candidate genes in Madhukar $\times$ Swarna RILs with contrasting levels of iron and zinc in unpolished rice grains. Gene 546, 430-436. doi: 10.1016/j.gene.2014.05.069

Ahuja, U., Ahuja, S. C., Thakrar, R., and Singh, R. K. (2008). Rice - A Nutraceutical. Asian Agrihist. 12, 93-108.

Anandan, A., Rajiv, G., Eswaran, R., and Prakash, M. (2011). Genotypic variation and relationships between quality traits and trace elements in traditional and improved rice (Oryza sativa L.) genotypes. J. Food Sci. 76, 122-130.

Anuradha, K., Agarwal, S., Batchu, A. K., Babu, A. P., Swamy, B. P. M., Longva, T., et al. (2012). Evaluating rice germplasm for iron and zinc concentration in brown rice and seed dimensions. J. Phytol. 4, 19-25.

Babu, V. R., Shreya, K., Dangi, K. S., Usharani, G., and Nagesh, P. (2012). Genetic variability studies for qualitative and quantitative traits in popular rice (Oryza sativa L.) hybrids of India. Int. J. Sci. Res. 2, 1-5.

Bashir, K., Takahashi, R., Akhtar, S., Ishimaru, Y., Nakanishi, H., and Nishizawa, N. K. (2013). The knockdown of OsVIT2 and MIT affects iron localization in rice seed. Rice 6:31. doi: 10.1186/1939-8433-6-31

Bekaert, S., Storozhenko, S., Mehrshah, P., Bennett, M. J., Lambert, W., Gregory, J. F., et al. (2008). Folate biofortification in food plants. Trends Plant Sci. 13, 28-35.

Bhattacharya, S., Sengupta, S., Karmakar, S., Sarkar, S. N., Gangopadhyay, G., Datta, K., et al. (2019). Genetically engineered rice with appA gene enhanced zinc rich and high protein rice varieties gives the optimistic message on the positive and forward move in rice crop enhancement program. The transgenic method will additionally support to improve grain nutrition to the desired level satisfactorily. On the basis of present evolutionary idea, it is believed that some transgenes from rice are not unsafe for the environment. On the other hand, some transgenes which do not have major selective advantages could cause partial or potential environmental problems. However, it is important to raise awareness of the factors influencing nutrient composition in the newly developed varieties. These newly developed rice varieties should undergo whole nutrient testing, environmental benefits and risks such as the impact on human health, environmental assessments and public accessibility in order to mark the standard for considering the impact of new varieties.

\section{AUTHOR CONTRIBUTIONS}

PD and AL generated the concept and made the outline of the review. PD and SA wrote the draft manuscript and prepared the tables and figures. AL finalized the manuscript. All authors contributed to the article and approved the submitted version.

\section{FUNDING}

PD was supported by the DST-SERB Young Scientist Project. AL was supported by an INSA Senior Scientist position, both operative at Bose Institute. SA was supported by the Rajib Gandhi National Fellowship (RGNF) of the University Grants Commission and Bose Institute.

phosphorus and minerals. J. Plant Biochem. Biotechnol. 28, 470-482. doi: 10. 1007/s13562-019-00505-3

Birla, D. S., Malik, K., Sainger, M., Chaudhary, D., Jaiwal, R., and Jaiwal, P. K. (2017). Progress and challenges in improving the nutritional quality of rice (Oryza sativa L.). Crit. Rev. Food Sci. Nutr. 57, 2455-2481.

Black, M. M. (2003). Micronutrient deficiencies and cognitive functioning. J. Nutr. 133, 3927S-3931S. doi: 10.1093/jn/133.11.3927s

Blancquaert, D., Van Daele, J., Strobbe, S., Kiekens, F., Storozhenko, S., Steur, H. D., et al. (2015). Improving folate (vitamin B9) stability in biofortified rice through metabolic engineering. Nat. Biotechnol. 33, 1076-1078. doi: 10.1038/nbt.3358

Bollini, R., and Chrispeels, M. J. (1978). Characterization and subcellular localization of vicilin and phytohemagglutinin the two major reserve proteins of Phaseolus vulgaris L. Planta 142, 291-298. doi: 10.1007/bf00385080

Brites, C. M., Trigo, M. J., Carrapico, B., Alvina, M., and Bessa, R. J. (2011). Maize and resistant starch enriched breads reduce postprandial glycemic responses in rats. Nutr. Res. 31, 302-308. doi: 10.1016/j.nutres.2011.02.001

Burkhardt, P. K., Beyer, P., Wunn, J., Kloti, A., Armstrong, G. A., Schledz, M., et al. (1997). Transgenic rice (Oryza sativa) endosperm expressing daffodil (Narcissus seudonarcissus) phytoene synthase accumulates phytoene, a key intermediate of provitaminA biosynthesis. Plant J. 11, 1071-1078. doi: 10.1046/j.1365-313x. 1997.11051071.x

Calayugan, M. I. C., Formantes, A. K., Amparado, A., Descalsota-Empleo, G. I., Nha, C. T., Inabangan-Asilo, M. A., et al. (2020). Genetic analysis of agronomic traits and grain iron and zinc concentrations in a doubled haploid population of rice (Oryza sativa L.). Sci. Rep. 10:2283. 
Chandel, G., Banerjee, S., See, S., Meena, R., Sharma, D. J., and Verulkar, S. B. (2010). Effects of different nitrogen fertilizer levels and native soil properties on rice grain Fe, $\mathrm{Zn}$ and protein contents. Rice Sci. 17, 213-227. doi: 10.1016/ s1672-6308(09)60020-2

Chattopadhaya, K., Behera, L., Bagchi, T. B., Sardar, S. S., Moharana, N., and Patra, N. N. (2019). Detection of stable QTLs for grain protein content in rice (Oryza sativa L.) employing high throughput phenotyping and genotyping. Sci. Rep. 9:3196.

Che, J., Yokosho, K., Yamaji, N., and Ma, J. F. (2019). A vacuolar phytosiderophore transporter alters iron and zinc accumulation in polished rice grains. Plant Physiol. 181, 276-288. doi: 10.1104/pp.19.00598

Chen, H., Siebenmorgen, T., and Griffin, K. (1998). Quality characteristics of long-grain rice milled in two commercial systems. Cereal Chem. 75, 560-565. doi: 10.1094/cchem.1998.75.4.560

Cheng, H. H., and Lai, M. H. (2000). Fermentation of resistant rice starch produces propionate reducing serum and hepatic cholesterol in rats. J. Nutr. 130, 19911995. doi: 10.1093/jn/130.8.1991

Chung, K. T., Wong, T. Y., Wei, C. I., Huang, Y. W., and Lin, Y. (1998). Tannins and human health: a review. Crit. Rev. Food Sci. Nutr. 38, 421-464.

Darnton-Hill, I., Webb, P., Harvey, P. W. J., Hunt, J. M., Dalmiya, N., Chopra, M., et al. (2005). Micronutrient deficiencies and gender: social and economic costs. Am. J. Clin. Nutr. 81, 1198S-1205S. doi: 10.1093/ajcn/81.5.1198

DellaPenna, D. (1999). Nutritional genomics: manipulating plant micronutrients to improve human health. Science 285, 375-379. doi: 10.1126/science.285. 5426.375

Deng, F., Yamaji, N., Ma, J. F., Lee, S. K., Jeon, J. S., Martinoia, E., et al. (2018). Engineering rice with lower grain arsenic. Plant Biotechnol. J. 16, 1691-1699. doi: $10.1111 /$ pbi.12905

Descalsota-Empleo, G. I., Amparado, A., Inabangan-Asilo, M. A., Tesoro, F., Stangoulis, J., Reinke, R., et al. (2019). Genetic mapping of QTL for agronomic traits andgrain mineral elements in rice. Crop. J. 7, 560-572. doi: 10.1016/j.cj. 2019.03.002

Dixit, S., Singh, U. M., Abbai, R., Ram, T., Singh, V. K., Paul, A., et al. (2019). Identification of genomic region(s) responsible for high iron and zinc content in rice. Sci. Rep. 9:8136.

Dolson, L. (2009). What You Need to Know About Complex Carbohydrates. Available at http://lowcarbdiets.about.com/od/nutrition/a/starch.htm (accessed March 24, 2020).

Dong, W., Cheng, Z., Lei, C., Wang, X. L., Wang, J. J., Wang, J., et al. (2014). Overexpression of folate biosynthesis genes in rice (Oryza sativa L.) and evaluation of their impact on seed folate content. Plant Food Hum. Nutr. 69, 379-385. doi: 10.1007/s11130-014-0450-9

FAO (2004). Rice Is Life. Available online at: http://www.fao.org/rice2004/en/fsheet/factsheet3.pdf

FAO/WHO (2001). Human Vitamin and Mineral Requirements.Report of a Joint FAO/WHO Expert Consultation Bangkok, Thailand. Available online at: http: //www.fao.org/docrep/004/y2809e/y2809e0m.htm

Frankard, V., Ghlslain, M., and Jacobs, M. (1992). Two feedback-insensitive enzymes of the aspartate pathway in Nicotiana sylvestris. Plant Physiol. 99, 1285-1293. doi: 10.1104/pp.99.4.1285

Frei, M., and Becker, K. (2004). On rice, Biodiversity and Nutrients. Institute of Animal Production in the Tropics and Subtropics. Stuttgart: University of Hohenheim.

Fuentes-Zaragoza, E., Sánchez-Zapata, E., Sendra, E., Sayas, E., Navarro, C., Fernández-López, J., et al. (2011). Resistant starch as prebiotic: a review. Starch 63, 406-415. doi: 10.1002/star.201000099

Galili, G. (2002). New insights into the regulation and functional significance of lysine metabolism in plants. Annu. Rev. Plant Biol. 53, 27-43.

Garcia-Oliveira, A. L., Tan, L., Fu, Y., and Sun, C. (2009). Genetic identification of quantitative trait loci for contents of mineral nutrients in rice grain. J. Integr. Plant Biol. 51, 84-92. doi: 10.1111/j.1744-7909.2008.00730.x

Garg, M., Sharma, N., Sharma, S., Kapoor, P., Kumar, A., Chunduri, V., et al. (2018). Biofortified crops generated by breeding, agronomy, and transgenic approaches are improving lives of millions of people around the world. Front. Nutr. 5:12. doi: 10.3389/fnut.2018.00012

Geisel, J. (2003). Folic acid and neural tube defects in pregnancy-a review. J. Perinat. Neonatal Nurs. 17, 268-279.
Goldstein, P. (2018). HarvestPlus Talks Zinc Rice with Farmers in Southeastern Bangladesh. Available online at: https://www.harvestplus.org/knowledgemarket/in-the-news/harvestplus-talks-zinc-rice-farmerssoutheastern-

bangladesh (accessed April 14, 2019).

Goto, F., Yoshihara, T., Shigemoto, N., Toki, S., and Takaiwa, F. (1999). Iron fortification of rice seed by the soybean ferritin gene. Nat. Biotechnol. 17, 282-286. doi: 10.1038/7029

Graham, R., Senadhira, D., Beebe, S., Iglesias, C., and Monasterio, I. (1999). Breeding for micronutrient density in edible portions of staple food crops: conventional approaches. Field Crop Res. 60, 57-80. doi: 10.1016/s03784290(98)00133-6

Graham, R. D., Welch, R. M., Saunders, D. A., Ortiz-Monasterio, I., Bouis, H. E., Bonierbale, M., et al. (2007). Nutritious subsistence food systems. Adv. Agron. 92, 1-74. doi: 10.1016/s0065-2113(04)92001-9

Gregorio, G. B. (2002). Progress in breeding for trace minerals in staple crops. J. Nutr. 132, 500-502.

Gregorio, G. B., Senadhira, D., Htut, H., and Graham, R. D. (2000). Breeding for trace mineral density in rice. Food Nutr. Bull. 21, 382-386. doi: 10.1177/ 156482650002100407

Grewal, P., and Sangha, J. (1990). Effect of processing on thiamine and riboflavin contents of some high-yielding rice varieties of Punjab. J. Food Sci. Technol. 52, 387-391. doi: 10.1002/jsfa.2740520311

Grist, D. H. (1986). Rice, 6th Edn. Singapore: Longman Singapore Publishers, 599.

Gupta, R. K., Gangoliya, S. S., and Singh, N. K. (2015). Reduction of phytic acid and enhancement of bioavailable micronutrients in food grains. J. Food Sci. Technol. 52, 676-684. doi: 10.1007/s13197-013-0978-y

Hagan, N. D., Upadhyaya, N., Tabe, L. M., and Higgins, T. J. V. (2003). The redistribution of protein sulfur in transgenic rice expressing a gene for a foreign, sulfur rich protein. Plant J. 34, 1-11. doi: 10.1046/j.1365-313x.2003.01699.x

Han, S. W., Chee, K. M., and Cho, S. J. (2015). Nutritional quality of rice bran protein in comparison to animal and vegetable protein. Food Chem. 172, 766-769. doi: 10.1016/j.foodchem.2014.09.127

Hanafy, M. S., Rahman, S. M., Khalafalla, M. M., El-Shemy, H. A., Nakamoto, Y., Ishimoto, M., et al. (2006). Accumulation of free tryptophan in azuki bean (Vignaangularis) induced by expression of a gene (OASA1D) for a modified $\alpha$ subunit of rice anthranilate synthase. Plant Sci. 171, 670-676. doi: 10.1016/j. plantsci.2006.06.016

Hasjim, J., Lee, S.-O., Hendrich, S., Setiawan, S., Ai, Y., and Jane, J.-L. (2010). Characterization of a novel resistant-starch and its effects on postprandial plasma-glucose and insulin responses. Cereal Chem. 87, 257-262. doi: 10.1094/ cchem-87-4-0257

Howson, C. P., Kennedy, E. T., and Horwitz, A. (eds) (1998). Prevention of Micronutrient Deficiencies: Tools for Policy Makers and Public Health Workers. Washington, DC: National Academy Press.

Huang, S., Wang, P., Yamaji, N., and Ma, J. F. (2020). Plant nutrition for human nutrition: hints from rice research and future perspectives. Mol. Plant 13, 825-835. doi: 10.1016/j.molp.2020.05.007

Huguchi, K., Suzuki, K., Nakanishi, H., Yamaguchi, H., Nishizawa, N. K., and Mori, S. (1999). Cloning of nicotaminesynthase genes, novel genes involved in the synthesis of phytosiderophores. Plant Physiol. 119, 471-479.

Hurrell, R. F., Reddy, M. B., Juillerat, M. A., and Cook, J. D. (2003). Degradation of phytic acid in cereal porridges improves iron absorption by human subjects. Am. J. Clin. Nutr. 77, 1213-1219. doi: 10.1093/ajcn/77.5.1213

Impa, S. M., Morete, M. J., Ismail, A. M., Schulin, R., and Johnson-Beebout, S. E. (2013). Zn uptake, translocation and grain $\mathrm{Zn}$ loading in rice (Oryza sativa L.) genotypes selected for $\mathrm{Zn}$ deficiency tolerance and high grain $\mathrm{Zn}$. J. Exp. Bot. 64, 2739-2751. doi: 10.1093/jxb/ert118

Inoue, H., Kobayashi, T., Nozoye, T., Takahashi, M., Kakei, Y., Suzuki, K., et al. (2009). Rice OsYSL15 Is an Iron-regulated Iron (III)-deoxymugineic acid transporter expressed in the roots and is essential for iron uptake in early growth of the seedlings. J. Biol. Chem 284, 3470-3479. doi: 10.1074/jbc.m806042200

Iqbal, S., Bhanger, M. I., and Anwar, F. (2005). Antioxidant properties and components of some commercially available varieties of rice bran in Pakistan. Food Chem. 93, 265-272. doi: 10.1016/j.foodchem.2004.09.024

Ishihara, A., Asada, Y., Takahashi, Y., Yabe, N., Komeda, Y., Nishioka, T., et al. (2006). Metabolic changes in Arabidopsis thaliana expressing the feedbackresistant anthranilate synthase $\alpha$ subunit gene OASA1D. Phytochemistry 67, 2349-2362. doi: 10.1016/j.phytochem.2006.08.008 
Ishikawa, S., Abe, T., Kuramata, M., Yamaguchi, M., Ando, T., Yamamoto, T., et al. (2010). A major quantitative trait locus for increasing cadmium-specific concentration in rice grain is located on the short arm of chromosome 7. J. Exp. Bot. 61, 923-934. doi: 10.1093/jxb/erp360

Ishikawa, S., Ishimaru, Y., Igura, M., Kuramata, M., Abe, T., Senoura, T., et al. (2012). Ionbeam irradiation, gene identification, and marker-assisted breeding in the development of low-cadmium rice. Proc. Natl. Acad. Sci. U.S.A. 109, 19166-19171. doi: 10.1073/pnas.1211132109

Ishimaru, Y., Bashir, K., and Nishizawa, N. (2011). Zn uptake and translocation in rice plants. Rice 4, 21-27. doi: 10.1007/s12284-011-9061-3

Ishimaru, Y., Masuda, H., Bashir, K., Inoue, H., Takashi, T., Nakanishi, H., et al. (2010). Rice metal-nicotianamine transporter, OsYSL2, is required for the longdistance transport of iron and manganese. Plant J. 62, 379-390. doi: 10.1111/j. 1365-313x.2010.04158.x

Ishimaru, Y., Masuda, H., Suzuki, M., Bashir, K., Takahashi, M., Nakanishi, H., et al. (2007). Over expression of the OsZIP4 zinc transporter confers disarrangement of zinc distribution in rice plants. J. Exp. Bot. 58, 2909-2915. doi: 10.1093/jxb/ erm 147

Ishimaru, Y., Suzuki, M., Kobayashi, T., Takahashi, M., Nakanishi, H., Mori, S., et al. (2005). OsZIP4, a novel zinc-regulated zinc transporter in rice. J. Exp. Bot. 56, 3207-3214. doi: 10.1093/jxb/eri317

Ishimaru, Y., Suzuki, M., Tsukamoto, T., Suzuki, K., Nakazono, M., Kobayashi, T., et al. (2006). Rice plants take up iron as an Fe3+-phytosiderophore and as Fe2+. Plant J. 45, 335-346. doi: 10.1111/j.1365-313x.2005.02624.x

Iwata, T. (2002). "Breeding, production physiology and quality of the famous Japanese rice variety Koshihikari," in Specialty Rices of the World: Breeding, Production and Marketing, eds R. C. Chaudhary, D. V. Tran, and R. Duffy (Rome: FAO), 243-248.

Iyer, R., and Tomar, S. K. (2009). Folate: a functional food constituent. J. Food Sci. 74, R114-R122.

Jeong, O. Y., Bombay, M., Ancheta, M. B., and Lee, J. H. (2020). QTL for the iron and zinc contents of the milled grains of a doubled-haploid rice (Oryza sativa L.) population grown over two seasons. J. Crop Sci. Biotechnol. doi: 10.1007/s12892-020-00037-6

Jiang, H., Lio, J., Blanco, M., Campbell, M., and Jane, J. L. (2010). Resistant starch formation in high-amylose maize starch during kernel development. J. Agric. Food Chem 58, 8043-8047. doi: 10.1021/jf101056y

Jiang, S. L., Wu, J. G., Feng, Y., Yang, X. E., and Shi, C. H. (2007). Correlation analysis of mineral element contents and quality traits in milled rice (Oryza sativa L). J. Agric. Food Chem. 55, 9608-9613. doi: 10.1021/jf071785w

Jiang, S. Y., Ma, A., Xie, L., and Ramachandran, S. (2016). Improving protein content and quality by over-expressing artificially synthetic fusion proteins with high lysine and threonine constituent in rice plants. Sci. Rep. 6:34427.

Jin, T., Zhou, J., Chen, J., Zhu, L., Zhao, Y., and Huang, Y. (2013). The genetic architecture of zinc and iron content in maize grains as revealed by QTL mapping and meta-analysis. Breed. Sci. 63, 317-324. doi: 10.1270/jsbbs.63.317

Johnson, A. A. T., Kyriacou, B., Callahan, D. L., Carruthers, L., Stangoulis, J., Lombi, E., et al. (2011). Constitutive overexpression of the OsNAS gene family reveals single-gene strategies for effective iron and zinc-biofortification of Rice endosperm. PLoS One 6:e24476. doi: 10.1371/journal.pone.0024476

Juliano, B. O. (1993). Rice in Human Nutrition. Rome: Food and Agriculture Organization of the United Nations (FAO).

Juliano, B. O., and Villareal, C. P. (1993). Grain Quality Evaluation of World Rices. Manila: International Rice Research Institute.

Kawakatsu, T., Hirose, S., Yasuda, H., and Takaiwa, F. (2010). Reducing rice seed storage protein accumulation leads to changes in nutrient quality and storage organelle formation. Plant Physiol. 154, 1842-1854. doi: 10.1104/pp.110.164343

Kim, S. A., and Guerinot, M. L. (2007). Mining iron: iron uptake and transport in plants. FEBS Lett. 581, 2273-2280. doi: 10.1016/j.febslet.2007.04.043

Kinoshita, N., Kato, M., Koyasak, K., Kawashima, T., Nishimura, T., and Hirayama, Y. (2017). Identification of quantitative trait loci for rice grain quality and yieldrelated traits in two closely related Oryza sativa L. subsp. japonica cultivars grown near the northern most limit for rice paddy cultivation. Breed. Sci. 67, 191-206. doi: 10.1270/jsbbs. 16155

Kline, K., Yu, W., and Sanders, B. G. (2004). Vitamin E and breast cancer. J. Nutr. 134,3458 S-3462S.
Kok, A. D., Yoon, L. L., Sekeli, R., Yeong, W. C., Yusof, Z. N. B., and Song, L. K. (2018). "Iron biofortification of rice: Progressand prospects," in Rice CropCurrent Developments, Vol. 3, eds F. Saha, Z. H. Khan, and A. Iqbal (London: Intech Open), 25-44.

Kreps, J. A., Ponappa, T., Dong, W., and Town, C. D. (1996). Molecular basis of $\alpha$-methyltryptophan resistance in amt-1, a mutant of Arabidopsis thaliana with altered tryptophan metabolism. Plant Physiol. 110, 1159-1165. doi: 10.1104/pp. 110.4.1159

Kuwano, M., Mimura, T., Takaiwa, F., and Yoshida, K. T. (2009). Generation of stable 'low phytic acid' transgenic rice through antisense repression of the 1D-myo-inositol 3-phosphate synthase gene (RINO1) using the $18-\mathrm{kDa}$ oleosin promoter. Plant Biotechnol. J. 7, 96-105. doi: 10.1111/j.1467-7652.2008. 00375.x

Lafiandra, D., Riccardi, G., and Shewry, P. R. (2014). Improving cereal grain carbohydrates for diet and health. J. Cereal Sci. 59, 312-326. doi: 10.1016/j. jcs.2014.01.001

Larson, S. R., Rutger, N., Young, K. A., and Raboy, V. (2000). Isolation and genetic mapping of a non-lethal rice (Oryza sativa L.) low phytic acid 1 Mutation. Crop Sci. 40, 1397-1405. doi: 10.2135/cropsci2000.4051397x

Lee, S., and An, G. (2009). Over-expression of OsIRT1 leads to increased iron and zinc accumulations in rice. Plant Cell Environ. 32, 408-416. doi: 10.1111/j. 1365-3040.2009.01935.x

Lee, S., Chiecko, J. C., Kim, S. A., Walker, E. L., Lee, Y., Guerinot, M. L., et al. (2009a). Disruption of OsYSL15 leads to inefficiency in rice plants. Plant Physiol. 150, 786-800. doi: 10.1104/pp.109.135418

Lee, S., Jeon, U. S., Lee, S. J., Kim, Y.-K., Persson, D. P., Husted, S., et al. (2009b). Iron fortification of rice seeds through activation of the nicotianamine synthase gene. Proc. Natl. Acad. Sci. U.S.A. 106, 22014-22019. doi: 10.1073/ pnas.0910950106

Lee, S., Kim, Y. S., Jeon, U. S., Kim, Y. K., Schjoerring, J. K., and An, G. (2012). Activation of rice nicotianamine synthase 2 (OsNAS2) enhances iron availability for biofortification. Mol. Cells 33, 269-275. doi: 10.1007/s10059012-2231-3

Lee, S., Persson, D. P., Hansen, T. H., Husted, S., Schjoerring, J. K., Kim, Y., et al. (2011). Bio-available zinc in rice seeds is increased by activation tagging of nictoianamine synthase. Plant Biotechnol. J. 9, 865-873. doi: 10.1111/j.14677652.2011.00606.x

Lee, S. M., Kang, J. W., Lee, J. Y., Seo, J., Shin, D., Cho, J. H., et al. (2020). QTL Analysis for $\mathrm{Fe}$ and $\mathrm{Zn}$ concentrations in rice grains using a doubled haploid population derived from a cross between rice (Oryza sativa) Cultivar 93-11 and Milyang 352. Plant Breed. Biotechnol. 8, 69-76. doi: 10.9787/pbb.2020.8.1.69

Lehrfeld, J. (1994). HPLC separation and quantitation of phytic acid and some inositol phosphates in foods: problems and solutions. J. Agric. Food Chem. 42, 2726-2731. doi: 10.1021/jf00048a015

Li, G. M., Presnell, S. R., and Gu, L. Y. (2003). Folate deficiency, mismatch repairdependent apoptosis, and human disease. J. Nutr. Biochem. 14, 568-575. doi: 10.1016/s0955-2863(03)00115-3

Liu, X., Zhang, C., Wang, X., Liu, Q., Yuan, D., Pan, G., et al. (2016). Development of high-lysine rice via endosperm-specific expression of a foreign LYSINE RICH PROTEIN gene. BMC Plant Biol. 16:147. doi: 10.1186/s12870-016-0837-x

Lloyd, B. J., Siebenmorgen, T. J., and Beers, K. W. (2000). Effects of commercial processing on antioxidants in rice bran. Cereal Chem. 75, 551-555. doi: 10. 1094/cchem.2000.77.5.551

Lopez, H. W., Levrat-Verny, M. A., Coudray, C., Besson, C., Krespine, V., Messager, A., et al. (2001). Class 2 resistant starches lower plasma and liver lipids and improve mineral retention in rats. J. Nutr. 131, 1283-1289. doi: 10.1093/jn/131.4.1283

Lu, K., Li, L., Zheng, X., Zhang, Z., Mou, T., and Hu, Z. (2008). Quantitative trait loci controlling $\mathrm{Cu}, \mathrm{Ca}, \mathrm{Zn}, \mathrm{Mn}$ and Fe content in rice grains. J. Genet. 87, 305-310. doi: 10.1007/s12041-008-0049-8

Lucca, P., Hurrell, R., and Potrykus, I. (2001). Genetic engineering approaches to improve the bioavailability and the level of iron in rice grains. Theor. Appl. Genet. 102, 392-397. doi: 10.1007/s001220051659

Ludwig, Y., and Slamet-Loedin, I. H. (2019). Genetic biofortification to enrich rice and wheat grain iron: from genes to product. Front. Plant Sci. 10:833. doi: $10.3389 /$ fpls. 2019.00833 
Mahender, A., Anandan, A., Pradhan, S. K., and Pandit, E. (2016). Grain nutritional traits and their enhancement using relevant genes and QTLs through advanced approaches. Springerplus 5:2086.

Majumder, S., Datta, K., and Datta, S. K. (2019). Rice biofortification: high iron, zinc, and Vitamin-A to fight against "Hidden Hunger". Agronomy 9:803. doi: 10.3390/agronomy9120803

Malik, S., and Chaudhary, P. (2002). "Non-conventional tools in the improvement of aromatic rices," in Specialty Rices of the World: Breeding, Production and Marketing, eds R. C. Chaudhary, D. V. Tran, and R. Duffy (Rome: FAO), 207-222.

Masuda, H., Aung, M. S., and Nishizawa, N. K. (2013a). Iron biofortification of rice using different transgenic approaches. Rice 6:40. doi: 10.1186/1939-8433-6-40

Masuda, H., Ishimaru, Y., Aung, M. S., Kobayashi, T., Kakei, Y., Takahashi, M., et al. (2012). Iron biofortification in rice by the introduction of multiple genes involved in iron nutrition. Sci. Rep. 2:543.

Masuda, H., Kobayashi, T., Ishimaru, Y., Takahashi, M., Aung, M. S., Nakanishi, H., et al. (2013b). Iron biofortification in rice by the introduction of three barley genes participated in mugineic acid biosynthesis with soybean ferritin gene. Front. Plant Sci. 4:132. doi: 10.3389/fpls.2013.00132

Masuda, H., Suzuki, M., Morikawa, K. C., Kobayashi, T., Nakanishi, H., Takahashi, M., et al. (2008). Increase in iron and zinc concentrations in rice grains via the introduction of barleygenes involved in phytosiderophore synthesis. Rice 1, 100-108. doi: 10.1007/s12284-008-9007-6

Masuda, H., Usuda, K., Kobayashi, T., Ishimaru, Y., Kakei, Y., Takahashi, M., et al. (2009). Overexpression of the barley nicotianamine synthase gene HvNAS1 increases iron and zinc concentrations in rice grains. Rice 2, 155-166. doi: 10.1007/s12284-009-9031-1

Mitani-Ueno, N., Yamaji, N., and Ma, J. F. (2018). “Transport system of mineral elements in rice," in Rice Genomics, Genetics and Breeding, eds T. Sasaki and M. Ashikari (Singapore: Springer), 223-240. doi: 10.1007/978-981-10-7461-5_13

Mitchikpe, C. E. S., Dossa, R. A. M., Ategbo, E. A. D., van Raaij, J. M. A., Hulshof, P. J. M., and Kok, F. J. (2008). The supply of bioavailable iron and zinc may be affected by phytate in Beninese children. J. Food Compost. Anal. 21, 17-25. doi: 10.1016/j.jfca.2007.06.006

Molina, L., Lapis, J. R., Sreenivasulu, N., and Cuevas, R. P. O. (2019). Determination of macronutrient and micronutrient content in rice grains using inductively coupled plasma-optical emission spectrometry (ICP-OES). Methods Mol. Biol. 1892, 253-264. doi: 10.1007/978-1-4939-8914-0_14

Muthayya, S., Sugimoto, J. D., Montgomery, S., and Maberly, G. F. (2014). An overview of global rice production, supply, trade, and consumption. Ann. N.Y. Acad. Sci. 1324, 7-14. doi: 10.1111/nyas. 12540

Negrutiu, I., Cattoir-Reyearts, A., Verbruggen, I., and Jacobs, M. (1984). Lysine overproducer mutants with an altered dihydrodopicolinate synthase from protoplast culture of Nicotianasylvestris (Spegazzini and Comes). Theor. Appl. Genet. 68, 11-20. doi: 10.1007/bf00252303

Nguyen, H. C., Hoefgen, R., and Hesse, H. (2012). Improving the nutritive value of rice seeds: elevation of cysteine and methionine contents in rice plants by ectopic expression of a bacterial serine acetyltransferase. J. Exp. Bot. 63, 5991-6001. doi: 10.1093/jxb/ers253

Norton, G. J., Deacon, C. M., Xiong, L., Huang, S., Meharg, A. A., and Price, A. H. (2010). Genetic mapping of the rice ionone in leaves and grain: identification of QTLs for 17 elements including arsenic cadmium iron and selenium. Plant Soil 329, 139-153. doi: 10.1007/s11104-009-0141-8

Nozoye, T., Nagasaka, S., Kobayashi, T., Takahashi, M., Sato, Y., Uozumi, N., et al. (2011). Phytosiderophore efflux transporters are crucial for iron acquisition in germinaceous plants. J. Biol. Chem. 286, 5446-5454. doi: 10.1074/jbc.m110. 180026

Oakley, G. P., Bell, K. N., and Weber, M. B. (2004). Recommendations for accelerating global action to prevent folic acid-preventable birth defects and other folate deficiency diseases: meeting of experts on preventing folic acidpreventable neural tube defects. Birth Defects Res. A Clin. Mol. Teratol. 70, 835-837. doi: 10.1002/bdra.20058

Oliva, N., Chadha-Mohanty, P., Poletti, S., Abrigo, E., Atienza, G., Torrizo, L., et al. (2013). Large-scale production and evaluation of marker-free indica rice IR64 expressing phytoferritin genes. Mol. Breed. 33, 23-37. doi: 10.1007/s11032013-9931-z

Paine, J. A., Shipton, C. A., Chaggar, S., Howells, R. M., Kennedy, M. J., Vernon, G., et al. (2005). Improving the nutritional value of Golden Rice through increased pro-vitamin A content. Nat. Biotechnol. 23, 482-487. doi: 10.1038/ nbt1082

Paul, S., Ali, N., Gayen, D., Datta, S. K., and Datta, K. (2012). Molecular breeding of Osfer2 gene to increase iron nutrition in rice grain. GM Crops Food 3, 310-316. doi: 10.4161/gmcr.22104

Peng, B., Kong, H., Li, Y., Wang, L., Zhong, M., Sun, L., et al. (2014). OsAAP6 functions as an important regulator of grain protein content and nutritional quality in rice. Nat. Commun. 5:4847.

Perera, I., Seneweera, S., and Hirotsu, N. (2018). Manipulating the phytic acid content of rice grain toward improving micronutrient bioavailability. Rice 11:4.

Phillips, J., Muir, J. G., Birkett, A., Lu, Z. X., Jones, G. P., O’Dea, K., et al. (1995). Effect of resistant starch on fecal bulk and fermentation dependent events in humans. Am. J. Clin. Nutr. 62, 121-130. doi: 10.1093/ajcn/62.1.121

Potrykus, I. (2008). Golden Rice and Other Biofortified Food Crops for Developing Countries - Challenges and Potential. Report from the Bertebos Conference in Falkenberg. (Slöige: KSLA), 1-111.

Pradhan, S. K., Pandit, E., Pawar, S., Naveenkumar, R., Barik, S. R., Mohanty, S. P., et al. (2020). Linkage disequilibrium mapping for grain $\mathrm{Fe}$ and $\mathrm{Zn}$ enhancing QTLs useful for nutrient dense rice breeding. BMC Plant Biol. 20:57. doi: 10.1186/s12870-020-2262-4

Prasad, A. S. (2004). Zinc deficiency: its characterization and treatment. Met. Ions Biol. Syst. 41, 103-137.

Qin, Y., Kim, S. M., and Sohn, J. K. (2009). QTL analysis of protein content in double-haploid lines of rice. Korean J. Crop Sci. 54, 165-171.

Qu, L. Q., Yoshihara, T., Ooyama, A., Goto, F., and Takaiwa, F. (2005). Iron accumulation does not parallel the high expression level of ferritin in transgenic rice seeds. Planta 222, 225-233. doi: 10.1007/s00425-005-1530-8

Raboy, V. (2000). Low-phytic-acid grains. Food Nutr. Bull. 21, 423-427. doi: $10.1177 / 156482650002100416$

Ramesh, S. A., Shin, R., Eide, D. J., and Schachtman, P. (2003). Differential metal selectivity andgeneexpression of two zinc transporters from rice. Plant Physiol. 133, 126-134. doi: 10.1104/pp.103.026815

Rao, D. S., Neeraja, C. N., Babu, P. M., Nirmala, B., Suman, K., and Rao, L. V. S. (2020). Zinc biofortified rice varieties: challenges, possibilities, and progress in India. Front. Nutr. 7:26. doi: 10.3389/fnut.2020.00026

Redondo, L. M., Chacana, P. A., Dominguez, J. E., and Fernandez, M. E. (2014). Perspectives in the use of tannins as alternative to antimicrobial growth promoter factors in poultry. Front. Microbiol. 5:118. doi: 10.3389/fmicb.2014. 00118

Regmi, P. R., Metzler-Zebeli, B. U., Gan̈zle, M. G., van Kempen, T. A., and Zijlstra, R. T. (2011). Starch with high amylose content and low in vitro digestibility increases intestinal nutrient flow and microbial fermentation and selectively promotes bifidobacteria in pigs. J. Nutr. 141, 1273-1280. doi: 10.3945/jn.111. 140509

Ricachenevsky, F. K., Vasconcelos, M. W., Shou, H., Johnson, A. A. T., and Sperotto, R. A. (2019). Improving the nutritional content and quality of crops: promises, achievements, and future challenges. Front. Plant Sci. 10:738. doi: 10.3389/fpls.2019.00738

Saha, S., Chakraborty, M., Padhan, D., Saha, B., Murmu, S., and Batabyal, K. (2017). Agronomic biofortification of zinc in rice: influence of cultivars and zinc application methods on grain yield and zinc bioavailability. Field Crops Res. 210, 52-60. doi: 10.1016/j.fcr.2017.05.023

Saika, H., Oikawa, A., Matsuda, F., Onodera, H., Saito, K., and Toki, S. (2011). Application of gene targeting to designed mutation breeding of hightryptophan rice. Plant Physiol. 156, 1269-1277. doi: 10.1104/pp.111.175778

Sasaki, A., Yamaji, N., and Ma, J. F. (2014). Over expression of OsHMA3 enhances $\mathrm{Cd}$ tolerance and expression of $\mathrm{Zn}$ transporter genes in rice. J. Exp. Bot. 65, 6013-6021. doi: 10.1093/jxb/eru340

Sasaki, A., Yamaji, N., and Ma, J. F. (2016). Transporters involved in mineral nutrient uptake in rice. J. Exp. Bot. 67, 3645-3653. doi: 10.1093/jxb/erw060

Sasaki, A., Yamaji, N., Yokosho, K., and Ma, J. F. (2012). Nramp5 is a major transporter responsible for manganese and cadmium uptake in rice. Plant Cell 24, 2155-2167. doi: 10.1105/tpc.112.096925

Saunders, R., and Betschart, A. (1979). Tropical Food: Chemistry and Nutrition, eds G. E. Inglett and G. Charalambous (New York, NY: Academic Press), 191-216.

Schaub, P., Al-Babili, S., and Beyer, P. (2005). Why is Golden Rice golden (yellow) instead of red? Plant Physiol. 138, 441-450. doi: 10.1104/pp.104. 057927 
Schramm, R., Abadie, A., Hua, N., Xu, Z., and Lima, M. (2007). Fractionation of the rice bran layer and quantification of vitamin $\mathrm{E}$, oryzanol, protein, and rice bran saccharide. J. Biol. Eng. 1:9. doi: 10.1186/1754-1611-1-9

Senadhira, D., Gregorio, G., and Graham, R. (1998). Paper presented at the international Workshop on Micronutrient Enhancement of Rice for Developing Countries. Stuttgart: Rice Research and Extension Center.

Shao, J. F., Xia, J., Yamaji, N., Shen, R. F., and Ma, J. F. (2018). Effective reduction of cadmium accumulation in rice grain by expressing OsHMA3 under the control of the OsHMA2 promoter. J. Exp. Bot. 69, 2743-2752. doi: 10.1093/jxb/ ery107

Shaul, O., and Galili, G. (1992). Increased lysine synthesis in transgenic tobacco plants expressing a bacterial dihydrodipicolinate synthase in their chloroplasts. Plant J. 2, 203-209. doi: 10.1111/j.1365-313x.1992.00203.x

Shewry, P. R., and Hey, S. J. (2015). The contribution of wheat to human diet and health. Food Energy Secur. 4, 178-202. doi: 10.1002/fes3.64

Shewry, P. R., Napier, J. A., and Tatham, A. S. (1995). Seed storage protein: structure and biosynthesis. Plant Cell 7, 945-956.

Singh, S. P., Gruissem, W., and Bhullar, N. K. (2017). Single genetic locus improvement of iron, zinc and $\beta$-carotene content in rice grains. Sci. Rep. $7: 6883$.

Singhal, N., and Austin, J. (2002). A clinical review of micronutrients in HIV infection. J. Int. Assoc. Physicians AIDS Care 1, 63-75.

Smith, M. R., and Myers, S. S. (2019). Global health implications of nutrient changes in rice under high atmospheric carbon dioxide. Geohealth 3, 190-200. doi: 10.1029/2019GH000188

Stangoulis, J. C. R., Huynh, B. L., Welch, R. M., Choi, E. Y., and Graham, R. D. (2007). Quantitative trait loci for phytate in rice grain and their relationship with grain micronutrient content. Euphytica 154, 289-294. doi: 10.1007/ s10681-006-9211-7

Stomph, T. J., Jiang, W., Van Der Putten, P. E., and Struik, P. C. (2014). Zinc allocation andre-allocation in rice. Front. Plant Sci. 5:8. doi: 10.3389/fpls.2014. 00008

Storozhenko, S., De Brouwer, V., Volckaert, M., Navarrete, O., Blancquaert, D., Zhang, G. F., et al. (2007). Folate fortification of rice by metabolic engineering. Nat. Biotechnol. 25, 1277-1279. doi: 10.1038/nbt1351

Sun, Q., Spiegelman, D., Van Dam, R. M., Holmes, M. D., Malik, V. S., Willett, W. C., et al. (2010). White rice, brown rice, and risk of Type 2 diabetes in US men and women. Arch. Intern. Med. 170, 961-969.

Sun, S. K., Chen, Y., Che, J., Konishi, N., Tang, Z., Miller, A. J., et al. (2018). Decreasing arsenic accumulation in rice by overexpressing OsNIP1;1 and OsNIP3;3 through disrupting arsenite radial transport in roots. New Phytol. 219, 641-653. doi: 10.1111/nph.15190

Suzuki, M., Morikawa, K. C., Nakanishi, H., Takahashi, M., Saigusa, M., Mori, S., et al. (2008). Transgenic rice lines that include barley genes have increased tolerance to low iron availability in a calcareous paddy soil. Soil Sci. Plant Nutr. 54, 77-85. doi: 10.1111/j.1747-0765.2007.00205.x

Swamy, B. P., Descalsota, G. I., Nha, C. T., Ampado, A., Asilo, M. A. I., Manito, C., et al. (2018a). Identification of genomic regions associated with agronomic and biofortification traits in DH populations of rice. PLoS One 13:e201756. doi: 10.1371/journal.pone.0201756

Swamy, B. P. M., Kaladhar, K., Anuradha, K., Batchu, A. K., Longvah, T., and Sarla, N. (2018b). QTL analysis for grain iron and zinc concentrations in two O. nivara derived backcross populations. Rice Sci. 25, 197-207. doi: 10.1016/j.rsci.2018. 06.003

Swamy, B. P. M., Rahman, M. A., and Inabangan-Asilo, M. A. (2016). Advances in breeding for high grain Zinc in Rice. Rice 9:49.

Swamy, B. P. M., Samia, M., Boncodin, R., Marundan, S., Rebong, D. B., Ordonio, R. L., et al. (2019). Compositional analysis of genetically engineered GR2E "Golden Rice" in comparison to that of conventional rice. J. Agric. Food Chem. 67, 7986-7994. doi: 10.1021/acs.jafc.9b01524

Takagi, S., Nomoto, K., and Takemoto, T. (1984). Physiological aspect of mugineic acid, a possible phytosiderophore of graminaceous plants. J. Plant Nutr. 7, 469-477. doi: 10.1080/01904168409363213

Tan, S., Han, R., Li, P., Yang, G., Li, S., Zhang, P., et al. (2015). Over-expression of the MxIRT1 gene increases iron and zinc content in rice seeds. Transgenic Res. 24, 109-122. doi: 10.1007/s11248-014-9822-Z

Tan, Y. F., Sun, M., Xing, Y. Z., Hua, J. P., Sun, X. L., Zhang, Q. F., et al. (2001). Mapping quantitative trait loci for milling quality, protein content and color characteristics of rice using a recombinant inbred line population derived from an elite rice hybrid. Theor. Appl. Genet. 103, 1037-1045. doi: 10.1007/ s001220100665

Tang, G., Qin, J., Dolnikowski, G. G., Russell, R. M., and Grusak, M. A. (2009). Golden Rice is an effective source of vitamin A. Am. J. Clin. Nutr. 89, 1776-1783. doi: 10.3945/ajcn.2008.27119

Tang, L., Mao, B., Li, Y., Lv, Q., Zhang, L., Chen, C., et al. (2017). Knockout of OsNramp5 using the CRISPR/Cas9 system produces low Cd-accumulating Indica rice without compromising yield. Sci. Rep 7:14438.

Theil, E. (1987). Ferritin: structure, gene regulation, and cellular function in animals, plants and microorganisms. Annu. Rev. Biochem. 56, 289-315. doi: 10.1146/annurev.bi.56.070187.001445

Tian, S., Nakamura, K., and Kayahara, H. (2004). Analysis of phenolic compounds in white rice, brown rice, and germinated brown rice. J. Agric. Food Chem. 52, 4808-4813. doi: 10.1021/jf049446f

Tian, Y. S., Wang, B., Peng, R. H., Xu, J., Li, T., Fu, X. Y., et al. (2019). Enhancing carotenoid biosynthesis in rice endosperm by metabolic engineering. Plant Biotechnol. J. 17, 849-851. doi: 10.1111/pbi.13059

Trijatmiko, K. R., Dueñas, C., Tsakirpaloglou, N., Torrizo, L., Arines, F. M., and Adeva, C. (2016). Biofortified Indica rice attains iron and zinc nutrition dietary targets in the field. Sci. Rep. 6:19792.

Ufaz, S., and Galili, G. (2008). Improving the content of essential amino acids in crop plants: goals and opportunities. Plant Physiol. 147, 954-961. doi: 10.1104/ pp.108.118091

Vasconcelos, M., Datta, K., Oliva, N., Khalekuzzaman, M., Torrizom, L., Krishnan, S., et al. (2003). Enhanced iron and zinc accumulation in transgenic rice with the ferritin gene. Plant Sci. 164, 371-378. doi: 10.1016/s0168-9452(02)00421-1

Wakasa, K., Hasegawa, H., Nemoto, H., Matsuda, F., Miyazawa, H., Tozawa, Y., et al. (2006). High-level tryptophan accumulation in seeds of transgenic rice and its limited effects on agronomic traits and seed metabolite profile. J. Exp. Bot. 57, 3069-3078. doi: 10.1093/jxb/erl068

Wang, L., Zhong, M. Z., Li, X., Yuan, D., Xu, Y., Liu, H., et al. (2008). The QTL controlling amino acid content in grains of rice (Oryza sativa) are co-localized with the regions involved in the amino acid metabolism pathway. Mol. Breed. 21, 127-137. doi: 10.1007/s11032-007-9141-7

Welch, R. M., and Graham, R. D. (2004). Breeding for micronutrients in staple food crops from a human nutrition perspective. J. Exp. Bot. 55, 353-364. doi: 10.1093/jxb/erh064

White, P. J., and Brown, P. H. (2010). Plant nutrition for sustainable development and global health. Ann. Bot. 105, 1073-1080. doi: 10.1093/aob/mcq085

Wirth, J., Poletti, S., Aeschlimann, B., Yakandawala, N., Drosse, B., Osorio, S., et al. (2009). Rice endosperm iron biofortification by targeted and synergistic action of nicotianamine synthase and ferritin. Plant Biotechnol. J. 7, 631-664.

Wong, H. W., Liu, Q., and Sun, S. S. M. (2015). Biofortification of rice with lysine using endogenous histones. Plant Mol. Biol. 87, 235-248. doi: 10.1007/s11103014-0272-z

World Health Organization [WHO] (2017). WHO Micronutrient Deficiencies WHO. Geneva: WHO.

Wu, C. Y., Lu, L. L., Yang, X. E., Geng, Y., Wei, Y. Y., Hao, H. L., et al. (2010). Uptake translocation and remobilization Zinc absorbed at different growth stages by rice genotypes of different $\mathrm{Zn}$ densities. J. Agric. Food Chem. 58, 6767-6773. doi: 10.1021/jf100017e

Wu, X. R., and Chen, Z. H. (2003). Enrichment of cereal protein lysine content by altered tRNAlys coding during protein synthesis. Plant Biotechnol. J. 1, 187-194. doi: 10.1046/j.1467-7652.2003.00017.x

Wu, X. R., Kenzior, A., Willmot, D., Scanlon, S., Chen, Z., Topin, A., et al. (2007). Altered expression of plant lysyl tRNA synthetase promotes tRNA misacylation and translational recoding of lysine. Plant J. 50, 627-636. doi: 10.1111/j.1365313x.2007.03076.x

Xu, M., Zhao, S., Zhang, Y., Yin, H., Peng, X., Cheng, Z., et al. (2017). Production of marker-free transgenic rice (Oryza sativa L.) with improved nutritive quality expressing AmA1. Iran. J. Biotechnol. 15, 102-110. doi: 10.15171/ijb.1527

Yamada, T., Matsuda, F., Kasai, K., Fukuoka, S., Kitamura, K., Tozawa, Y., et al. (2008). Mutation of a rice gene encoding a phenylalanine biosynthetic enzyme results in accumulation of phenylalanine and tryptophan. Plant Cell 20, 13161329. doi: $10.1105 /$ tpc. 107.057455

Yamada, Y., Tozawa, Y., Ohkawa, Y., and Wakasa, K. (2004). Use of a feedbackinsensitive alpha subunit of anthranilate synthase as a selectable marker for transformation of rice and potato. Mol. Breed. 14, 363-373. doi: 10.1007/ s11032-005-0184-3 
Yamaji, N., and Ma, J. F. (2017). Node-controlled allocation of mineral elements in Poaceae. Curr. Opin. Plant Biol. 39, 18-24. doi: 10.1016/j.pbi.2017.05.002

Yamaji, N., Takemoto, Y., Miyaji, T., Mitani-Ueno, N., Yoshida, K. T., and Ma, J. F. (2017). Reducing phosphorus accumulation in rice grains with an impaired transporter in the node. Nature 541, 92-95. doi: 10.1038/nature20610

Yamaji, N., Xia, J., Mitani-Ueno, N., Yokosho, K., and Ma, J. F. (2013). Preferential delivery of zinc to developing tissues in rice is mediated by P-type heavy metal ATPase OsHMA2. Plant Physiol. 162, 927-939. doi: 10.1104/pp.113.216564

Yang, Q. Q., Zhang, C. Q., Chan, M. I., Zhao, D. S., Chen, J. Z., Wang, Q., et al. (2016). Biofortification of rice with the essential amino acid lysine: molecular characterization, nutritional evaluation, and field performance. J. Exp. Bot. 67, 4258-4296.

Yang, Q. Q., Zhao, D. S., Zhang, C. Q., Wu, H. Y., Li, Q. F., Gu, M. H., et al. (2018). A connection between lysine and serotonin metabolism in rice endosperm. Plant Physiol. 176, 1965-1980. doi: 10.1104/pp.17.01283

Yang, Y., Guo, M., Sun, S., Zou, Y., Yin, S., Liu, Y., et al. (2019). Natural variation of OsGluA2 is involved in grain protein content regulation in rice. Nat. Commun. 10:1949.

Ye, X., Babili, S. A., Kloti, A., Lucca, P., Beyer, P., and Potrykus, I. (2000). Engineering the provitamin A ( $\beta$-Carotene) biosynthetic pathway into (Carotenoid-Free) rice endosperm. Science 287, 303-305. doi: 10.1126/science. 287.5451.303

Yin, H. J., Gao, X. P., Stomph, T., Li, L., Zhang, F., and Zou, C. Q. (2016). Zinc concentration in rice (Oryza sativa L.) grains and allocation in plants as affected by different zinc fertilization strategies. Commun. Soil Sci. Plant Anal. 47, 761-768. doi: 10.1080/00103624.2016.1146891

Yu, Y.-H., Li, G., Fan, Y.-Y., Zhang, K.-Q., Min, J., Zhu, Z.-W., et al. (2009). Genetic relationship between grain yield and the contents of protein and fat in a recombinant inbred population of rice. J. Cereal Sci. 50, 121-125. doi: 10.1016/j.jcs.2009.03.008

Yun, B.-W., Kim, M.-G., Handoyo, T., and Kim, K.-M. (2014). Analysis of rice grain quality-associated quantitative trait loci by using genetic mapping. Am. J. Plant Sci. 5, 1125-1132. doi: 10.4236/ajps.2014.59125

Zhang, W., Bi, J., Chen, L., Zheng, L., Ji, S., Xia, Y., et al. (2008). QTL mapping for crude protein and protein fraction contents in rice (Oryza sativa L.). J. Cereal Sci. 48, 539-547. doi: 10.1016/j.jcs.2007.11.010

Zhang, L., Hu, B., Deng, K., Gao, X., Sun, G., Zhang, Z., et al. (2019). NRT1.1B improves selenium concentrations in rice grains by facilitating selenomethinone translocation. Plant Biotechnol. J. 17, 1058-1068. doi: 10. 1111/pbi.13037
Zhang, Y., Li, X., Chen, W., Yi, B., Wen, J., Shen, J., et al. (2011). Identification of two major QTL for yellow seed color in two crosses of resynthesized Brassica napus line No. 2127-17. Mol. Breed. 28, 335-342. doi: 10.1007/s11032-0109486-1

Zhang, M., Pinsin, S. R. M., Tarpley, L., Huang, X.-Y., Lahner, B., Yakubova, E., et al. (2014). Mapping and validation of quantitative trait loci associated with concentration of 16 elements in unmilled rice grain. Theor. Appl. Genet. 127, 137-165. doi: 10.1007/s00122-013-2207-5

Zheng, Z., Sumi, K., Tanaka, K., and Murai, N. (1995). The bean seed storage protein [beta]-Phaseolin is synthesized, processed, and accumulated in the vacuolar type-II protein bodies of transgenic rice endosperm. Plant Physiol. 109, 777-786. doi: 10.1104/pp.109.3.777

Zhong, M., Wang, L.-Q., Yuan, D.-J., Luo, L.-J., Xu, C.-G, and He, Y.-Q. (2011). Identification of QTL affecting protein and amino acid contents in rice. Rice Sci. 18, 187-195. doi: 10.1016/s1672-6308(11)60026-7

Zhu, L., Gu, M., Meng, X., Cheung, S. C. K., Yu, H., Huang, J., et al. (2012). High-amylose rice improves indices of animal health in normal and diabetic rats. Plant Biotechnol. J. 10, 353-362. doi: 10.1111/j.1467-7652.2011. 00667.x

Zhu, Q., Wang, B., Tan, J., Liu, T., Li, L., and Liu, Y.-G. (2019). Plant synthetic metabolic engineering for enhancing crop nutritional quality. Plant Commun. 1:100017. doi: $10.1016 /$ j.xplc.2019.100017

Zhu, Q., Yu, S., Zeng, D., Liu, H., Wang, H., Yang, Z., et al. (2017). Development of "Purple Endosperm Rice" by engineering anthocyanin biosynthesis in the endosperm with a high-efficiency transgene stacking system. Mol. Plant 10, 918-929.

Zhu, Q., Zeng, D., Yu, S., Cui, C., Li, J., Li, H., et al. (2018). From Golden Rice to aSTARice: bioengineering astaxanthin biosynthesis in rice endosperm. Mol. Plant 11, 1440-1448. doi: 10.1016/j.molp.2018.09.007

Conflict of Interest: The authors declare that the research was conducted in the absence of any commercial or financial relationships that could be construed as a potential conflict of interest.

Copyright (c) 2020 Das, Adak and Lahiri Majumder. This is an open-access article distributed under the terms of the Creative Commons Attribution License (CC BY). The use, distribution or reproduction in other forums is permitted, provided the original author(s) and the copyright owner(s) are credited and that the original publication in this journal is cited, in accordance with accepted academic practice. No use, distribution or reproduction is permitted which does not comply with these terms. 